\title{
A Strategy to Conjugate Bioactive Fragments to Cytotoxic Diiron Bis(cyclopentadienyl) Complexes
}

\author{
Silvia Schoch, Mouna Hadiji, Sarah A. P. Pereira, M. Lúcia M. F. S. Saraiva, Simona Braccini, \\ Federica Chiellini, Tarita Biver, Stefano Zacchini, Guido Pampaloni, Paul J. Dyson, and Fabio Marchetti*
}

Cite This: Organometallics 2021, 40, 2516-2528

Read Online

ACCESS | Llll Metrics \& More | 国 Article Recommendations | sl Supporting Information

ABSTRACT: A series of bioactive molecules were synthesized from the condensation of aspirin or chlorambucil with terminal alkynes bearing alcohol or amine substituents. Insertion of the resulting alkynes into the iron-carbyne bond of readily accessible diiron bis(cyclopentadienyl) $\mu$-aminocarbyne complexes, $[\mathbf{1} \mathbf{a}, \mathbf{b}] \mathrm{CF}_{3} \mathrm{SO}_{3}$, afforded novel diiron complexes with a bridging vinyliminium ligand, $[\mathbf{2}-\mathbf{1 0}] \mathrm{CF}_{3} \mathrm{SO}_{3}$, functionalized with a bioactive moiety. All compounds were characterized by elemental analysis and IR and multinuclear NMR spectroscopy and in three cases by single-crystal X-ray diffraction. Moreover, the $\mathrm{D}_{2} \mathrm{O}$ solubility, stability in $\mathrm{D}_{2} \mathrm{O}$ and cell culture media, and octanol-water partition coefficients of diiron complexes were determined spectroscopically. The cytotoxicity of the complexes was assessed in the tumorigenic A2780 and A2780cisR and the nontumorigenic HEK 293T cell lines. Some complexes exhibit high potency and the ability to overcome

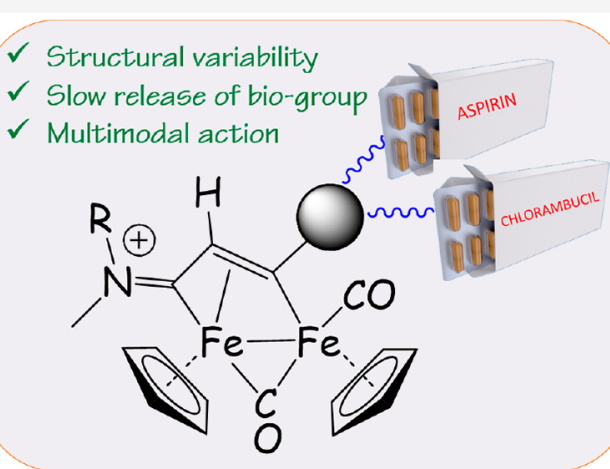
resistance in A2780cisR cells (aspirin complexes) or high selectivity relative to HEK 293T cells (chlorambucil complexes). Further studies indicate that the complexes significantly trigger intracellular ROS production, irrespective of the nature of the bioactive fragment. DNA alkylation and protein binding studies were also undertaken.

\section{INTRODUCTION}

Platinum anticancer compounds have been extensively employed in the clinic but have important limitations due to the occurrence of severe side effects and both intrinsic and acquired resistance. ${ }^{1}$ Therefore, compounds based on other transition metals have been widely investigated for their anticancer potential. ${ }^{2}$ In this context, iron has emerged as an attractive element, being bioessential and basically nontoxic in many forms, ${ }^{3}$ and especially ferrocifens, resulting from the conjugation of the ferrocene skeleton with the drug tamoxifen, hold much promise. ${ }^{4}$ The redox chemistry of the ferrocenyl iron(II) center is the key to the cytotoxicity, with oxidation to $\mathrm{Fe}^{\mathrm{III}}$ in the tumor environment triggering the production of toxic metabolites, leading to DNA damage and cell death. ${ }^{5}$ Additionally, some piano-stool monoiron cyclopentadienyl complexes display potent cytotoxicity against various tumor cell lines. ${ }^{6}$ However, the assessment of the anticancer properties of diiron complexes still remains undeveloped, despite opportunities offered by the cooperativity of two metal centers. Indeed, bimetallic systems often enable reactivity patterns not accessible to homologous monometallic compounds, with significant catalytic and biological implications. ${ }^{8}$ A useful diiron platform is represented by $\left[\mathrm{Fe}_{2} \mathrm{Cp}_{2}(\mathrm{CO})_{4}\right](\mathrm{Cp}$ $\left.=\eta^{5}-\mathrm{C}_{5} \mathrm{H}_{5}\right)$, where the carbonyl ligands can be progressively replaced by small unsaturated molecules, leading to unusual organic fragments stabilized by coordination to both metal centers. ${ }^{9}$ In particular, bridging vinyliminium ligands can be constructed from isocyanide-alkyne coupling reactions (Figure 1). ${ }^{10}$ The broad availability of alkynes permits a vast choice of substituents for the vinyliminium ligand, modulating the physicochemical properties of the cationic complexes. Recently, we reported a variety of cationic diiron vinyliminium compounds that are cytotoxic against A2780 and A2780cisR cell lines, with $\mathrm{IC}_{50}$ values spanning from nanomolar concentrations to inactivity, depending on the substituents. ${ }^{11-13}$ According to preliminary studies, the mode of action seems multitargeted, involving ROS production. Antiproliferative activity is maintained in neutral derivatives containing a modified vinyliminium chain. ${ }^{14}$

A general and effective strategy to enhance the anticancer activity of metal complexes consists of the incorporation of an organic fragment with known biological activity, including clinically approved drugs, within the metal scaffold. ${ }^{15}$ Synthetic methods include direct coordination of the bioactive group to the metal and the use of a suitable ligand as a linker between

Received: May 3, 2021

Published: July 2, 2021 

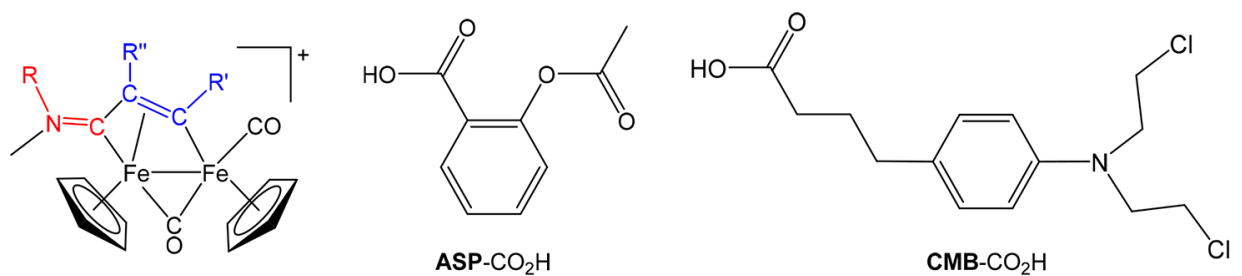

Figure 1. General structure of diiron $\mu$-vinyliminium complexes obtained from the assembly of one isocyanide (fragment in red) and one alkyne (fragment in blue), starting from $\mathrm{Fe}_{2} \mathrm{Cp}_{2}(\mathrm{CO})_{4}$ and structures of aspirin $\left(\mathbf{A S P}-\mathrm{CO}_{2} \mathrm{H}\right)$ and chlorambucil $\left(\mathbf{C M B}-\mathrm{CO}_{2} \mathrm{H}\right)$.

Scheme 1. Synthesis of Terminal Alkynes Derivatized with Aspirin or Chlorambucil ${ }^{a}$

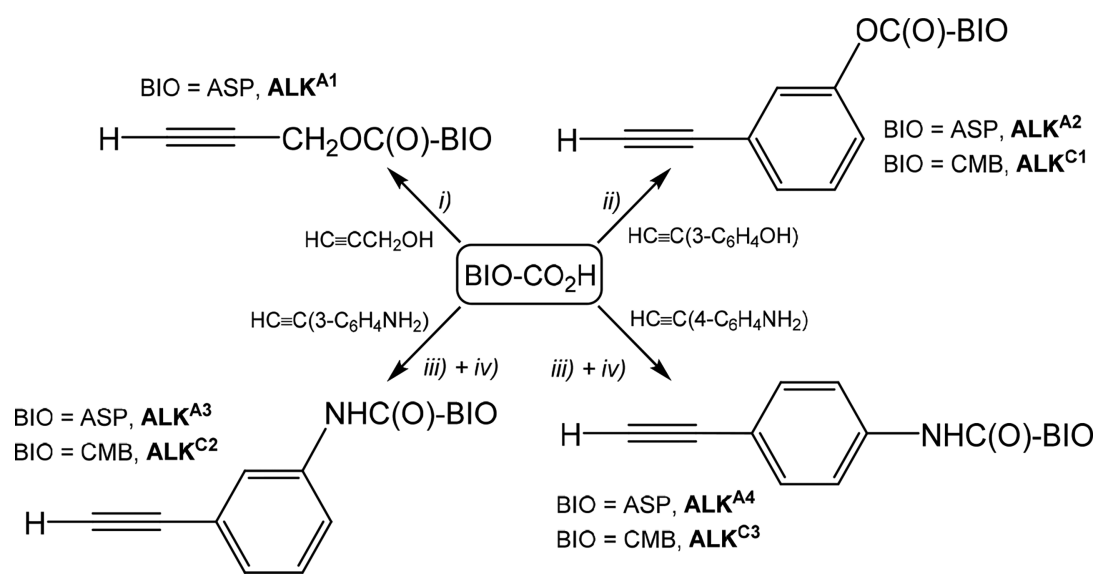

${ }^{a}$ Reaction conditions: $\mathrm{CH}_{2} \mathrm{Cl}_{2}$ solution, room temperature; (i) and (ii) EDCI $\cdot \mathrm{HCl} / \mathrm{DMAP}$; (iii) $\mathrm{BIO}-\mathrm{CO}_{2} \mathrm{H}+$ oxalyl chloride/DMF; (iv) +alkyne/ $\mathrm{NEt}_{3}$.

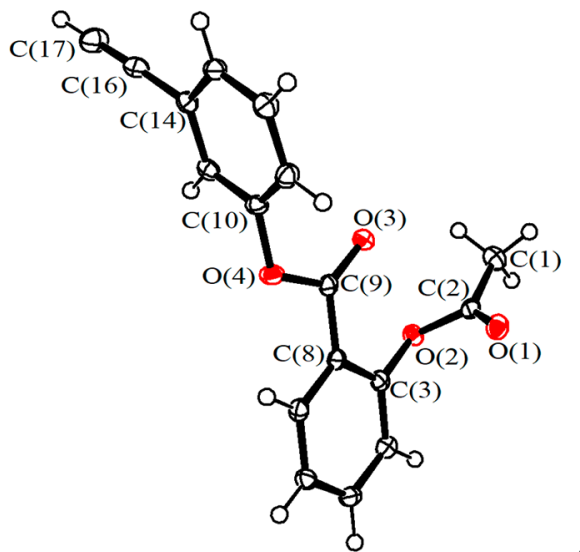

(a)

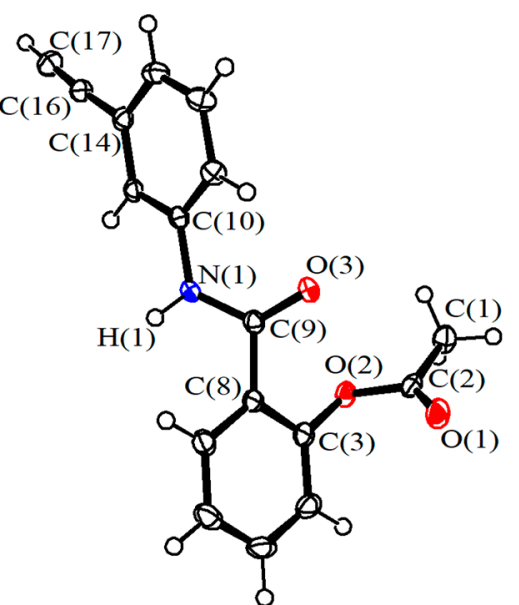

(b)

Figure 2. Molecular structures of (a) $\mathbf{A L K}^{\mathbf{A} 2}$ and (b) $\mathbf{A L K}^{\mathbf{A} 3}$ with key atoms labeled. Displacement ellipsoids are at the 30\% probability level. Main bond distances $(\AA)$ and angles (deg) for $\mathrm{ALK}^{\mathrm{A2}}$ : C $(1)-\mathrm{C}(2)$ 1.4913(16), C(2)-O(1) 1.1947(13), C(2)-O(2) 1.3718(13), O(2)-C(3) $1.3947(13), \mathrm{C}(8)-\mathrm{C}(9)$ 1.4905(14), $\mathrm{C}(9)-\mathrm{O}(3)$ 1.1984(13), C(9)-O(4) 1.3600(13), O(4)-C(10) 1.4050(13), C(14)-C(16) 1.4383(15), $\mathrm{C}(16)-\mathrm{C}(17) 1.1840(17), \mathrm{C}(1)-\mathrm{C}(2)-\mathrm{O}(2) 109.80(9), \mathrm{C}(2)-\mathrm{O}(2)-\mathrm{C}(3) 116.37(8), \mathrm{C}(8)-\mathrm{C}(9)-\mathrm{O}(4) 109.85(9), \mathrm{C}(9)-\mathrm{O}(4)-\mathrm{C}(10)$ 117.57(8), C (14)-C(16)-C(17) 177.99(12). Main bond distances $(\AA)$ and angles (deg) for $\mathrm{ALK}^{\mathrm{A} 3}$ : $\mathrm{C}(1)-\mathrm{C}(2) 1.4827(16, \mathrm{C}(2)-\mathrm{O}(1)$ $1.2030(14), \mathrm{C}(2)-\mathrm{O}(2) 1.3532(13), \mathrm{O}(2)-\mathrm{C}(3) 1.3965(13), \mathrm{C}(8)-\mathrm{C}(9) 1.5035(15), \mathrm{C}(9)-\mathrm{O}(3) 1.2210(13), \mathrm{C}(9)-\mathrm{N}(1) 1.3577(14), \mathrm{N}(1)-$ $\mathrm{C}(10)$ 1.4191(13), C(14)-C(16) 1.4400(16), C(16)-C(17) 1.1873(17), C(1)-C(2)-O(2) 110.18(9), C(2)-O(2)-C(3) 117.30(8), C(8)$\mathrm{C}(9)-\mathrm{N}(1)$ 114.60(9), C(9)-N(1)-C(10) 124.23(9), C(14)-C(16)-C(17) 175.31(12) Hydrogen bonds for ALK $\mathrm{A}^{\mathrm{A}}(\AA \mathrm{A}$ and deg): N(1)-H(1) $0.883(12), \mathrm{H}(1) \cdots \mathrm{O}(1) \# 1$ 2.006(12), $\mathrm{N}(1) \cdots \mathrm{O}(1) \# 1$ 2.8653(12), $\angle \mathrm{N}(1) \mathrm{H}(1) \mathrm{O}(1) \# 1$ 164.0(12). Symmetry transformation: (\#1) $x+1 / 2, y,-z$ $+1 / 2$.

such two entities. ${ }^{16}$ The ligand--biomolecule connection might consist of either an ester or an amide function, and these two different linkers may significantly affect the mode of action and, hence, the cytotoxicity. ${ }^{17}$ The cyclopentadienyl $\operatorname{ring}(s)$ in ferrocenes have been extensively derivatized with bioactive molecules, ${ }^{18}$ e.g. ferrocifens (see above), ${ }^{19}$ whereas examples with non-ferrocene iron species are rare. ${ }^{20}$

Relevant to the present work, the inclusion of acetylsalicylic acid (aspirin) and chlorambucil (Figure 1) within $\mathrm{Pt}^{\mathrm{IV}}$ and $\mathrm{Ru}^{\mathrm{II}}$ anticancer complexes has resulted in synergistic effects on 
cancer cells originating from the two components. ${ }^{21,22}$ Aspirin, one of the most widely used medicines in the world, possesses analgesic, antipyretic, and anti-inflammatory properties, which are associated with the inactivation of COX-1 and COX-2 enzymes, and anticancer properties have been recently evidenced. $^{23}$ On the other hand, chlorambucil is a DNA alkylating agent approved by the FDA for oral administration in the treatment of chronic lymphocytic leukemia and some other tumors. 22,24

Here, we report a straightforward synthetic strategy allowing the attachment of a bioactive molecule, i.e. aspirin or chlorambucil, to a diiron scaffold which itself displays anticancer activity. This method is applicable to both ester and amide linkages. The resulting functionalized complexes have been assessed for their cytotoxicity, and experiments to elucidate mechanistic aspects have been carried out.

\section{RESULTS AND DISCUSSION}

Synthesis and Characterization of Compounds. The bioderivatized alkynes $\mathbf{A L K}^{\mathrm{A} 1}, \mathrm{ALK}^{\mathrm{A} 2}, \mathrm{ALK}^{\mathrm{A} 3}$, and $\mathrm{ALK}^{\mathrm{A4}}$ (aspirin-alkynes) and $\mathbf{A L K}^{\mathrm{C} 1}, \mathbf{A L K}^{\mathrm{C} 2}$ and $\mathbf{A L K}^{\mathrm{C} 3}$ (chlorambucil-alkynes) were prepared via condensation reactions of propargyl alcohol, 3-hydroxyphenylacetylene, 3-aminophenylacetylene, and 4-aminophenylacetylene with the appropriate carboxylic acid, i.e. ASP- $\mathrm{CO}_{2} \mathrm{H}$ or $\mathbf{C M B}-\mathrm{CO}_{2} \mathrm{H}$, using different protocols (Scheme 1). The products were purified by silica chromatography and then isolated as white/light yellow solid/ oily materials in $51-95 \%$ yield.

The alkyne $\mathbf{A L K}^{\mathrm{Al}}$ was previously reported, ${ }^{25}$ while the remaining alkynes are unprecedented and were fully characterized by elemental analysis and IR and NMR spectroscopy. In the IR spectra (solid state), the triple carbon-carbon bond manifests itself by a weak absorption around $2100 \mathrm{~cm}^{-1}$, whereas the amide $\mathrm{NH}$ group in $\mathbf{A L K} \mathbf{K}^{\mathrm{A} 3}$, $\mathbf{A L K}^{\mathrm{A} 4}, \mathbf{A L K}^{\mathrm{C} 2}$, and $\mathbf{A L K}^{\mathrm{C} 3}$ absorbs as a medium-intensity stretching band at ca. $3250 \mathrm{~cm}^{-1}$. The infrared band of the carbonyl belonging to the alkyne-BIO linkage falls within the ranges $1721-1757 \mathrm{~cm}^{-1}$ (ester) and $1652-1673 \mathrm{~cm}^{-1}$ (amide). The ${ }^{1} \mathrm{H}$ NMR spectra $\left(\mathrm{CDCl}_{3}\right.$ solutions) display a resonance due to the alkyne $\mathrm{CH}$ proton in the range 2.56-3.56 ppm, with the $\mathrm{NH}$ of amide-containing species being observed between 7.35 and $9.30 \mathrm{ppm}$. In the ${ }^{13} \mathrm{C}$ NMR spectra, the carbonyl groups give rise to a resonance between 162.7 and $171.8 \mathrm{ppm}$. The NMR signals due to the bioactive cores do not significantly differ from the corresponding signals of aspirin ${ }^{26}$ and chlorambucil. ${ }^{27}$ The molecular structures of $\mathbf{A L K}^{\mathrm{A} 2}$ and ALK $^{\mathrm{A3}}$ were confirmed by single-crystal X-ray diffraction (Figure 2).

In order to obtain the functionalized diiron complexes, the $\mu$-aminocarbyne complexes $\left[\mathrm{Fe}_{2} \mathrm{Cp}_{2}(\mathrm{CO})_{2}(\mu\right.$-CO $)\{\mu$-CNMe(R) $\}] \mathrm{CF}_{3} \mathrm{SO}_{3}\left(\mathrm{R}=\mathrm{Me},[\mathbf{1 a}] \mathrm{CF}_{3} \mathrm{SO}_{3} ; \mathrm{R}=\mathrm{Xyl}=2,6-\mathrm{C}_{6} \mathrm{H}_{3} \mathrm{Me}_{2}\right.$, $\left.[\mathrm{lb}] \mathrm{CF}_{3} \mathrm{SO}_{3}\right)$, readily available from a multigram-scale synthesis, were first converted into the mono(acetonitrile) adducts $\left[\mathrm{Fe}_{2} \mathrm{Cp}_{2}(\mathrm{CO})(\mathrm{NCMe})(\mu\right.$-CO $)\{\mu$-CNMe $\left.(\mathrm{R})\}\right] \mathrm{CF}_{3} \mathrm{SO}_{3} \quad(\mathrm{R}=$ $\mathrm{Me}, \mathrm{Xyl}){ }^{28}$ Then, the latter complexes, in dichloromethane solution, were treated with a slight molar excess of the alkyne, thus allowing a highly regio- and stereoselective alkyne insertion into the iron-bridging carbyne bond upon removal of the labile acetonitrile ligand (Scheme 2).

Complexes $[2-10] \mathrm{CF}_{3} \mathrm{SO}_{3}$ were isolated in $48-96 \%$ yield after workup and fully characterized by elemental analysis and IR and NMR spectroscopy. The IR spectra $\left(\mathrm{CH}_{2} \mathrm{Cl}_{2}\right.$ solutions) share a common pattern with two bands due to terminal
Scheme 2. Two-Step Synthesis of Diiron Vinyliminium Complexes via Coupling of Bridging Aminocarbyne Ligands with Aspirin- and Chlorambucil-Functionalized Alkynes $\left(\mathrm{CF}_{3} \mathrm{SO}_{3}^{-}\right.$Salts $)$
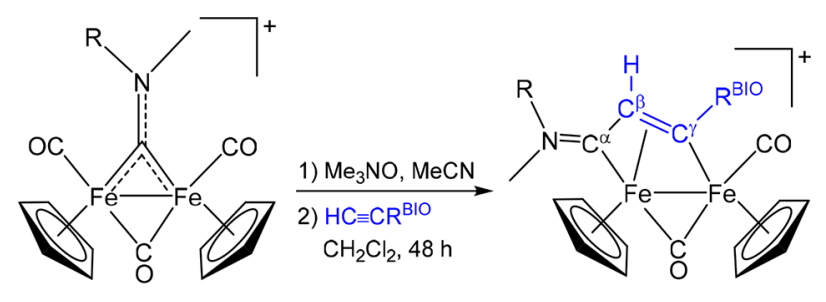

\begin{tabular}{|c|c|c|}
\hline$R$ & alkyne & \\
\hline Xyl & $\mathbf{A L K}^{\mathrm{A} 1}$ & {$[2]^{+}$} \\
\hline $\mathrm{Me}$ & $\mathrm{ALK}^{\mathrm{A} 2}$ & {$[3]^{+}$} \\
\hline Xyl & $\mathbf{A L K}^{\mathrm{A} 2}$ & {$[4]^{+}$} \\
\hline $\mathrm{Me}$ & $\mathbf{A L K}^{\mathrm{A} 3}$ & {$[5]^{+}$} \\
\hline $\mathrm{Xyl}$ & $\mathbf{A L K}^{\mathrm{A} 3}$ & {$[6]^{+}$} \\
\hline $\mathrm{Me}$ & $\mathbf{A L K}^{\mathrm{A4}}$ & {$[7]^{+}$} \\
\hline $\mathrm{Me}$ & ALK $^{\mathrm{C} 1}$ & {$[8]^{+}$} \\
\hline $\mathrm{Me}$ & $\mathbf{A L K}^{\mathrm{C} 2}$ & {$[9]^{+}$} \\
\hline $\mathrm{Me}$ & ALK $^{\mathrm{C} 3}$ & {$[\mathbf{1 0}]^{+}$} \\
\hline
\end{tabular}

(1991-2007 $\mathrm{cm}^{-1}$ ) and bridging carbonyl ligands (1807$\left.1820 \mathrm{~cm}^{-1}\right)$ and another band related to the $\left\{\mathrm{C}_{\beta} \mathrm{C}_{\alpha} \mathrm{N}\right\}^{10 a}$ moiety $\left(1628-1692 \mathrm{~cm}^{-1}\right)$. The ester linkages between the vinyliminium and the bioactive fragment in $[2-4,8] \mathrm{CF}_{3} \mathrm{SO}_{3}$ absorb in the $1727-1758 \mathrm{~cm}^{-1}$ range, whereas the amido carbonyl groups belonging to $[5-7,9-10] \mathrm{CF}_{3} \mathrm{SO}_{3}$ are observed at $1678-1691 \mathrm{~cm}^{-1}$. The ${ }^{1} \mathrm{H}$ NMR spectra of $[2,6] \mathrm{CF}_{3} \mathrm{SO}_{3}$ (acetone- $d_{6}$ solutions) contain two sets of resonances, due to $E-Z$ isomerism arising from the different substituents on the iminium nitrogen, with prevalence of the $E$ form $\left(E / Z\right.$ ratio $=2$ for $[2] \mathrm{CF}_{3} \mathrm{SO}_{3}$ and 9 for $\left.[6] \mathrm{CF}_{3} \mathrm{SO}_{3}\right)$. The other complexes exist as single isomeric species, including $[4] \mathrm{CF}_{3} \mathrm{SO}_{3}$, which is present in solution as the $E$ isomer only. Comparisons with a library of data related to nonfunctionalized diiron vinyliminium complexes indicate that the $\mathrm{Cp}$ ligands exclusively adopt a mutual cis geometry in all compounds $[2-10] \mathrm{CF}_{3} \mathrm{SO}_{3} .{ }^{10-12,29} \mathrm{C}_{\beta}$ - $\mathrm{H}$ resonates at $4.4-$ $4.8 \mathrm{ppm}$ and is negligibly affected by the adjacent $\mathrm{C}_{\gamma}$ substituent; the $\mathrm{NH}$ amide proton in $[5-7,9-10] \mathrm{CF}_{3} \mathrm{SO}_{3}$ is slightly deshielded in comparison to the alkyne precursors and is observed at around $9.5 \mathrm{ppm}$. Salient ${ }^{13} \mathrm{C}$ NMR features are given by the resonances related to the vinyliminium carbon chain, respectively in the intervals $224.3-232.4 \mathrm{ppm}\left(\mathrm{C}_{\alpha}\right)$, 48.6-53.8 ppm $\left(\mathrm{C}_{\beta}\right)$, and 200.7-207.8 ppm $\left(\mathrm{C}_{\gamma}\right)$, thus evidencing the alkylidene character of $\mathrm{C}_{\alpha}$ (amino-alkylidene) and $\mathrm{C}_{\gamma}$. The chemical shifts for the ester/amide linkage carbon in $[2-10] \mathrm{CF}_{3} \mathrm{SO}_{3}$ do not differ significantly with respect to the biofunctionalized alkynes.

The structure of $[2] \mathrm{CF}_{3} \mathrm{SO}_{3}$ was elucidated by X-ray diffraction (Figure 3). The cation is composed of a $\left[\mathrm{Fe}_{2} \mathrm{Cp}_{2}(\mathrm{CO})(\mu\right.$-CO) $]$ skeleton, with the Cp-ligands in a cis geometry, and a $\left\{\mu-\eta^{1}: \eta^{3}-\mathrm{C}^{3}(\mathrm{R}) \mathrm{C}^{2} \mathrm{HC}{ }^{1} \mathrm{~N}(\mathrm{Me})(\mathrm{Xyl})\right\}^{+}$vinyliminium ligand bearing the aspirin moiety $\left(\mathrm{R}=\mathrm{CH}_{2} \mathrm{OC}(\mathrm{O})\right.$ $\left.\mathrm{C}_{6} \mathrm{H}_{4} \mathrm{OC}(\mathrm{O}) \mathrm{CH}_{3}\right)$. The bridging alkylidene $\mathrm{C}^{3}$ carbon is slightly asymmetric with respect to the Fe centers ( $\mathrm{Fe}(1)-$ $\mathrm{C}(3) 2.016(6) \AA, \mathrm{Fe}(2)-\mathrm{C}(3)$ 1.945(6) $\AA$ ), and a more pronounced asymmetry is observed for the $\mu$-CO ligand $(\mathrm{Fe}(1)-\mathrm{C}(31) 1.971(6) \AA, \mathrm{Fe}(2)-\mathrm{C}(31) 1.876(6) \AA)$. The $\mathrm{C}(1)-\mathrm{N}(1)$ distance $(1.295(8) \AA)$ is indicative of an iminium bond, although the $\mathrm{Fe}(1)-\mathrm{C}(1)$ distance (1.831(6) $\AA$ ) possesses some aminoalkylidene nature, in agreement with 


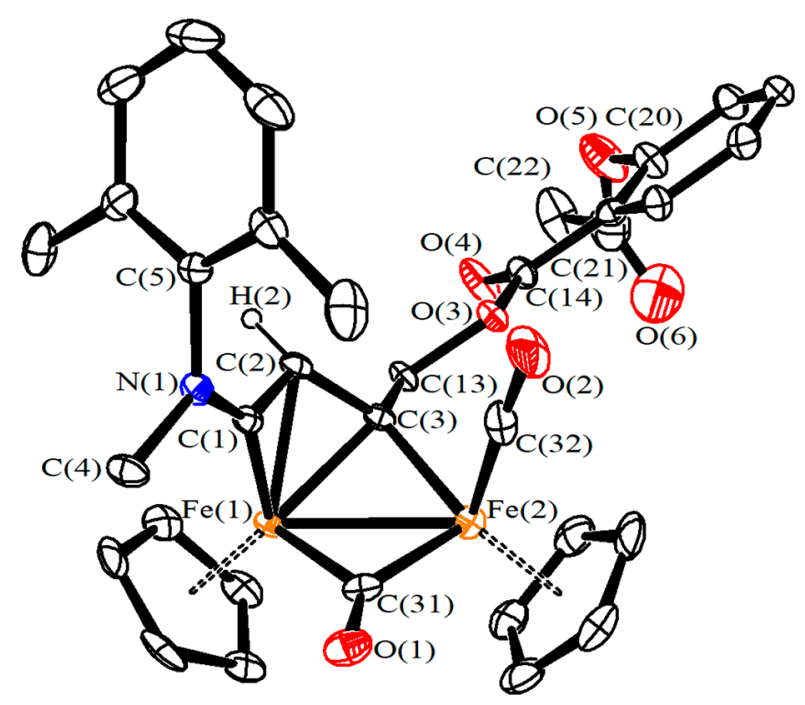

Figure 3. View of the cation of $[2] \mathrm{CF}_{3} \mathrm{SO}_{3}$ with key atoms labeled. Displacement ellipsoids are at the $30 \%$ probability level. Hydrogen atoms, except $\mathrm{H}(2)$, have been omitted for clarity. Main bond distances $(\AA)$ and angles (deg): $\mathrm{Fe}(1)-\mathrm{Fe}(2) 2.5421(12), \mathrm{Fe}(1)-$ $\mathrm{C}(31)$ 1.971(6), $\mathrm{Fe}(2)-\mathrm{C}(31)$ 1.876(6), $\mathrm{Fe}(2)-\mathrm{C}(32) 1.758(8)$ $\mathrm{Fe}(1)-\mathrm{C}(3) 2.016(6), \mathrm{Fe}(2)-\mathrm{C}(3) 1.945(6), \mathrm{Fe}(1)-\mathrm{C}(2) 2.042(6)$, $\mathrm{Fe}(1)-\mathrm{C}(1)$ 1.831(6), $\mathrm{C}(31)-\mathrm{O}(1)$ 1.172(8), $\mathrm{C}(32)-\mathrm{O}(2)$ 1.153(9), $\mathrm{C}(1)-\mathrm{N}(1)$ 1.295(8), $\mathrm{C}(1)-\mathrm{C}(2) 1.411(8), \mathrm{C}(2)-\mathrm{C}(3)$ 1.416(9), $\mathrm{C}(3)-\mathrm{C}(13)$ 1.511(8), $\mathrm{C}(13)-\mathrm{O}(3)$ 1.446(7), O(3)$\mathrm{C}(14)$ 1.326(7), $\mathrm{C}(14)-\mathrm{O}(4) \quad 1.210(8), \mathrm{Fe}(1)-\mathrm{C}(31)-\mathrm{Fe}(2)$ $82.7(2), \quad \mathrm{Fe}(1)-\mathrm{C}(3)-\mathrm{Fe}(2) \quad 79.8(2), \mathrm{Fe}(2)-\mathrm{C}(32)-\mathrm{O}(2)$ 175.5(7), $\mathrm{Fe}(2)-\mathrm{C}(3)-\mathrm{C}(2) \quad 122.2(4), \quad \mathrm{C}(3)-\mathrm{C}(2)-\mathrm{C}(1)$ $116.6(5), \quad \mathrm{C}(2)-\mathrm{C}(1)-\mathrm{N}(1) \quad 134.5(6), \quad \mathrm{C}(3)-\mathrm{C}(13)-\mathrm{O}(3)$ 105.1(5), $\quad \mathrm{C}(13)-\mathrm{O}(3)-\mathrm{C}(14) \quad 116.1(5), \quad \mathrm{O}(3)-\mathrm{C}(14)-\mathrm{O}(4)$ 123.1(6).

the ${ }^{13} \mathrm{C}$ NMR spectrum. ${ }^{10,11}$ The iminium group adopts an $E$ conformation which corresponds to the prevalent conformation detected in solution by NMR spectroscopy (see above).

Solubility and Stability in Aqueous Media and Octanol-Water Partition Coefficients. The solubility of the complexes in $\mathrm{D}_{2} \mathrm{O}$ was assessed using ${ }^{1} \mathrm{H}$ NMR spectroscopy (see Table 1 and the Experimental Section for details). Complexes $[3] \mathrm{CF}_{3} \mathrm{SO}_{3},[5] \mathrm{CF}_{3} \mathrm{SO}_{3}$, and $[7] \mathrm{CF}_{3} \mathrm{SO}_{3}$ possess appreciable water solubility, whereas the solubility values for the remaining compounds are low. Data from the literature for the related nonfunctionalized complexes $\left[2^{\prime}, 3^{\prime}\right]$ $\mathrm{CF}_{3} \mathrm{SO}_{3}$ are compiled in Table 1 for comparison. ${ }^{11}$ The octanol-water partition coefficients $\left(\log P_{\text {ow }}\right)$ were measured using a UV-vis method and fall within the -0.2 to +1.2 range (Table 1 ). The structural variability provided by the synthetic route offers much opportunity for fine-tuning the lipophilicity of the complexes, which is significantly influenced by the iminium substituents, the type of linkage to the bioactive group (i.e., ester or amide), and its location on the aryl ring. For instance, $\log P_{\text {ow }}$ values of 1.07 and 0.65 are obtained for the geometric isomers $[9] \mathrm{CF}_{3} \mathrm{SO}_{3}$ and $[10] \mathrm{CF}_{3} \mathrm{SO}_{3}$, respectively.

Stability studies in deuterated aqueous medium at $37{ }^{\circ} \mathrm{C}$ were carried out using ${ }^{1} \mathrm{H}$ NMR spectroscopy and evidenced partial release (approximately 20\%) of aspirin $\left(\mathrm{Asp}-\mathrm{CO}_{2} \mathrm{H}\right)$ from the $\left\{\mathrm{CH}_{2}-\mathrm{OCOAsp}\right\}$ linkage within $[2] \mathrm{CF}_{3} \mathrm{SO}_{3}$ after 24 $\mathrm{h}$ (see Figure S40 in the Supporting Information), to give the hydrolyzed alcohol derivative $\left[\mathbf{2}^{\prime}\right]^{+}$(Figure 4). Conversely, [3-7] $\mathrm{CF}_{3} \mathrm{SO}_{3}$, containing either $\{$ Aryl-OCOAsp $\}$ or $\{$ ArylNHCOAsp $\}$ moieties, were stable under the same conditions. The ester bond connecting chlorambucil to the aryl unit in
Table 1. Solubility in $\mathrm{D}_{2} \mathrm{O}$ (based on ${ }^{1} \mathrm{H}$ NMR Spectroscopy, $\mathrm{Me}_{2} \mathrm{SO}_{2}$ as Internal Standard) and Partition Coefficients $\left(\log P_{\text {ow }}\right)$ of Diiron Complexes $\left(T=21^{\circ} \mathrm{C}\right)$ and Residual Percent of cComplex in $\mathrm{D}_{2} \mathrm{O} / \mathrm{DMSO} 2 / 1 \mathrm{v} / \mathrm{v}$ Mixture after $24 \mathrm{~h}$ at $37^{\circ} \mathrm{C}$

\begin{tabular}{cclr} 
compound & solubility $\left(\mathrm{mol} \mathrm{L}^{-1}\right)$ & \multicolumn{1}{c}{$\log P_{\text {ow }}$} & stability (\%) \\
{$[\mathbf{2}] \mathrm{CF}_{3} \mathrm{SO}_{3}$} & $<1 \times 10^{-4}$ & $0.40 \pm 0.01$ & $85(69)^{a}$ \\
{$[\mathbf{3}] \mathrm{CF}_{3} \mathrm{SO}_{3}$} & $7.8 \times 10^{-4}$ & $0.24 \pm 0.01$ & $81(57)^{a}$ \\
{$[\mathbf{4}] \mathrm{CF}_{3} \mathrm{SO}_{3}$} & $<1 \times 10^{-4}$ & $1.06 \pm 0.04$ & 59 \\
{$[\mathbf{5}] \mathrm{CF}_{3} \mathrm{SO}_{3}$} & $1.1 \times 10^{-3}$ & $-0.10 \pm 0.01$ & 69 \\
{$[\mathbf{6}] \mathrm{CF}_{3} \mathrm{SO}_{3}$} & $<1 \times 10^{-4}$ & $0.80 \pm 0.02$ & 91 \\
{$[7] \mathrm{CF}_{3} \mathrm{SO}_{3}$} & $5.3 \times 10^{-4}$ & $-0.19 \pm 0.01$ & 70 \\
{$[\mathbf{8}] \mathrm{CF}_{3} \mathrm{SO}_{3}$} & $<1 \times 10^{-4}$ & $1.2 \pm 0.2$ & $84(77)^{a, b}$ \\
{$[\mathbf{9}] \mathrm{CF}_{3} \mathrm{SO}_{3}$} & $<1 \times 10^{-4}$ & $1.07 \pm 0.05$ & $88^{b}$ \\
{$[\mathbf{1 0}] \mathrm{CF}_{3} \mathrm{SO}_{3}$} & $<1 \times 10^{-4}$ & $0.65 \pm 0.02$ & $93(85)^{a, b}$ \\
{$\left[\mathbf{2}^{\prime}\right] \mathrm{CF}_{3} \mathrm{SO}_{3}{ }^{c}$} & $1.0 \times 10^{-3}$ & -0.1 & \\
{$\left[\mathbf{3}^{\prime}\right] \mathrm{CF}_{3} \mathrm{SO}_{3}{ }^{c}$} & $1.4 \times 10^{-2}$ & -0.34 &
\end{tabular}

${ }^{a}$ The residual percentage of the complex after $72 \mathrm{~h}$ at $37^{\circ} \mathrm{C}$ is given in parentheses. ${ }^{b}$ Total percentage of diiron complexes with a chlorambucil-like group in $\mathrm{D}_{2} \mathrm{O} / \mathrm{DMSO} 1 / 1 \mathrm{v} / \mathrm{v}$ mixture. ${ }^{c}$ Values from ref 11 .

$[8] \mathrm{CF}_{3} \mathrm{SO}_{3}$ did not undergo hydrolysis; nevertheless, gradual chloride/hydroxide exchange occurred within the peripheral chlorambucil moiety, affording $\left[8^{\mathrm{OH}}\right]^{+}$and $\left[\mathbf{8}^{\mathbf{2 O H}}\right]^{+}$(Figure 4; their identity was confirmed by HPLC-MS). Complete conversion into the bis-hydroxide $\left[\mathbf{8}^{2 \mathrm{OH}}\right]^{+}$was achieved within $72 \mathrm{~h}$. Similarly, $[\mathbf{9 , 1 0}] \mathrm{CF}_{3} \mathrm{SO}_{3}$ undergo activation of the $\{\mathrm{C}-$ $\mathrm{Cl}\}$ bonds to give mixtures of the partially $\mathrm{Cl} / \mathrm{OH}$ substituted species $\left[\mathbf{9}^{\mathrm{OH}}\right]^{+}$and $\left[\mathbf{1 0}^{\mathrm{OH}}\right]^{+}$and the fully substituted species $\left[9^{2 \mathrm{OH}}\right]^{+}$and $\left[10^{2 \mathrm{OH}}\right]^{+}$.

Complexes $[3] \mathrm{CF}_{3} \mathrm{SO}_{3},[5] \mathrm{CF}_{3} \mathrm{SO}_{3}$, and $[8] \mathrm{CF}_{3} \mathrm{SO}_{3}$ were selected for an evaluation of their stability in the culture medium. Compounds were dissolved in DMSO- $d_{6}$, and these solutions were diluted with the cell culture medium and stored at $37^{\circ} \mathrm{C}$. According to NMR spectroscopy, progressive release of the bioactive fragment occurred over $72 \mathrm{~h}$, affording $\left[3^{\prime}\right]^{+}$ from $[3] \mathrm{CF}_{3} \mathrm{SO}_{3}$ and $\left[\mathbf{5}^{\prime}\right]^{+}$from $[\mathbf{5}] \mathrm{CF}_{3} \mathrm{SO}_{3}$ (Figures $\mathrm{S} 41$ and $\mathrm{S} 42$ ). The amide linkage between aspirin and the diiron frame in $[5] \mathrm{CF}_{3} \mathrm{SO}_{3}$ was found to be weaker than the corresponding ester bond in $[3] \mathrm{CF}_{3} \mathrm{SO}_{3}$, and complete dissociation was observed after $72 \mathrm{~h}$ for the former complex. The ${ }^{1} \mathrm{H}$ NMR spectrum suggests that chlorambucil release from $[8] \mathrm{CF}_{3} \mathrm{SO}_{3}$ is accompanied by the gradual hydrolysis of the two chloroethyl groups, as observed in $\mathrm{D}_{2} \mathrm{O} / \mathrm{DMSO}-d_{6}$. Overall, these findings indicate that the diiron scaffold decorated with biofunctionalized vinyliminium ligands is robust in aqueous media, with a tendency to progressively release the bioactive moiety in the medium used in cytotoxicity studies.

Cytotoxicity Studies. The antiproliferative activity of the new diiron complexes $[\mathbf{2}-\mathbf{1 0}] \mathrm{CF}_{3} \mathrm{SO}_{3}$ and that of cisplatin as a reference was assessed toward cisplatin-sensitive and cisplatinresistant human ovarian cancer cell lines, A2780 and A2780cisR, respectively, and the noncancerous HEK 293T cell line. The results are compiled in Table 2, where they are compared to those previously reported for $\left[2^{\prime}, 3^{\prime}\right] \mathrm{CF}_{3} \mathrm{SO}_{3}{ }^{11}$ $[\mathbf{l a}, \mathbf{b}] \mathrm{CF}_{3} \mathrm{SO}_{3}{ }^{7}$ chlorambucil, ${ }^{22 \mathrm{~b}}$ and aspirin. ${ }^{30}$ In general, a correlation exists between the $\mathrm{IC}_{50}$ and $\log P_{\text {ow }}$ values, the most lipophilic compounds being also the most active. With regard to the aspirin-containing complexes [2-7] $\mathrm{CF}_{3} \mathrm{SO}_{3}$, these exhibit a comparable level of activity against the two cancer cell lines; in particular, $[4]^{+}$and $[6]^{+}$are strongly 

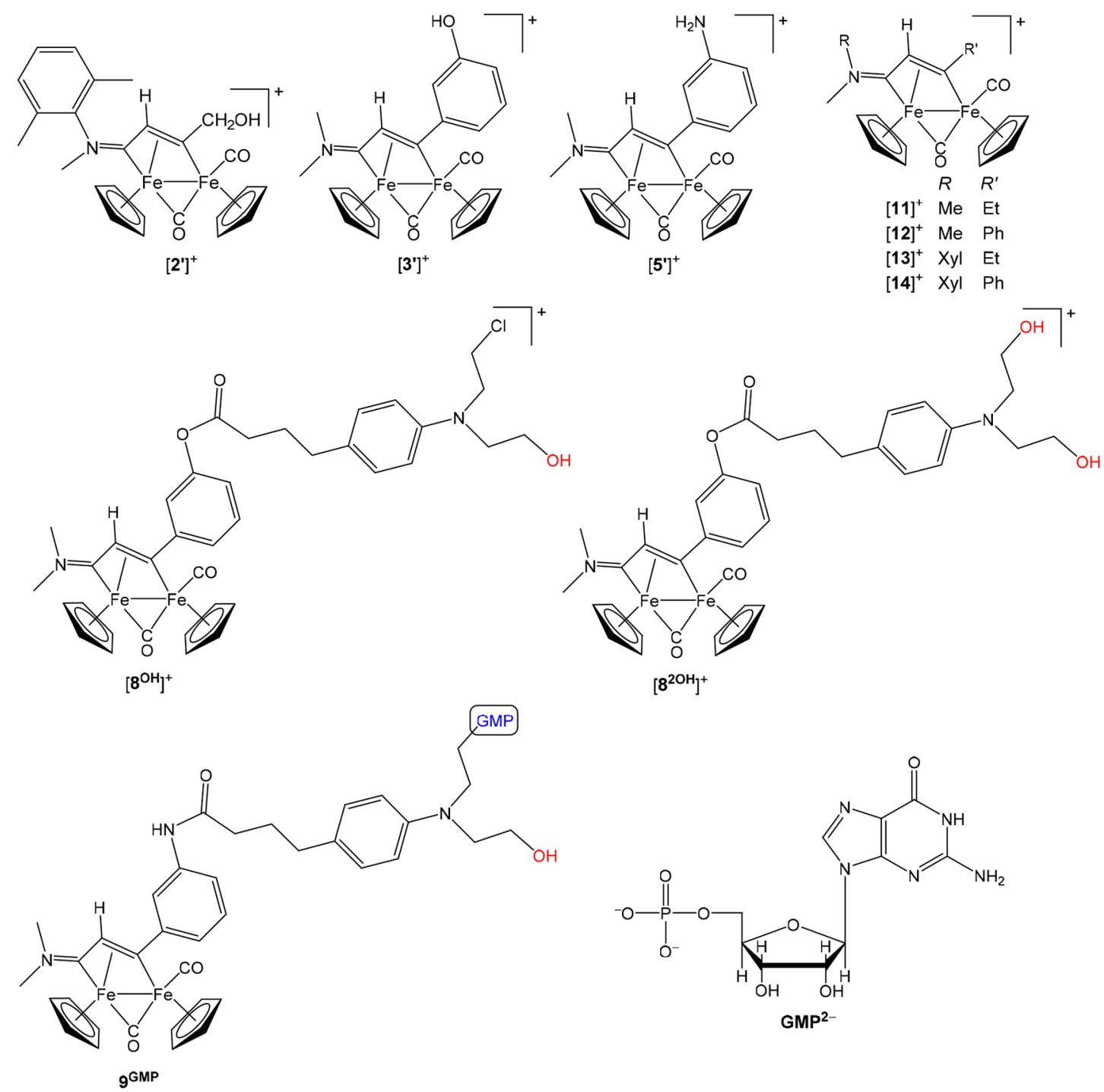

Figure 4. Structures of diiron complexes discussed in this work in addition to those shown in Scheme 2: $\left[\mathbf{2}^{\prime}\right]^{+},\left[\mathbf{3}^{\prime}\right]^{+},\left[\mathbf{5}^{\prime}\right]^{+},\left[\mathbf{8}^{\mathrm{OH}}\right]^{+}$, and $\left[\mathbf{8}^{\mathbf{2 O H}}\right]^{+}$ formed upon release of the bioactive fragments in aqueous/biological media; $9^{\mathrm{GMP}}$ formed upon interaction of $[9]^{+}$with the model nucleotide guanosine $5^{\prime}$-monophosphate (disodium salt, $\mathrm{Na}_{2}[\mathrm{GMP}]$ ); $[\mathbf{1 1 - 1 4}]^{+}$investigated for COX-2 inhibition assays. The structures of $\left[8^{\mathrm{OH}}\right]^{+}$and $\left[8^{2 \mathrm{OH}}\right]^{+}$are also representative of those of the homologous complexes $\left[9^{\mathrm{OH}}\right]^{+},\left[10^{\mathrm{OH}}\right]^{+},\left[\mathbf{9}^{2 \mathrm{OH}}\right]^{+}$, and $\left[10^{2 \mathrm{OH}}\right]^{+}($not shown).

cytotoxic with $\mathrm{IC}_{50}$ values falling in the low-micromolar range. The performance of the chlorambucil derivative $[9] \mathrm{CF}_{3} \mathrm{SO}_{3}$ is notable, since this complex displays a potent cytotoxicity against the A2780 cell line, a significant selectivity $(\mathrm{SI}=5)$, and an enhanced ability to overcoming cisplatin resistance ( $\mathrm{IC}_{50}$ on A2780cisR cell line $7.9 \mu \mathrm{M}$ for cisplatin, $3.8 \mu \mathrm{M}$ for $\left.[9] \mathrm{CF}_{3} \mathrm{SO}_{3}\right)$. The performance of $[9] \mathrm{CF}_{3} \mathrm{SO}_{3}$ against the cancer cell lines is superior to that of chlorambucil. The chlorambucil complex $[8] \mathrm{CF}_{3} \mathrm{SO}_{3}$, differing from $[9] \mathrm{CF}_{3} \mathrm{SO}_{3}$ in the presence of an ester group instead of an amide, also displays some selectivity, but it is not as effective as the aspirin complexes in the cisplatin-resistant cell line. Overall, the attachment of bioactive fragments to the diiron scaffold leads to a marked effect on the activity of the complexes. Finally, it should be mentioned that the cytotoxicity of the vinyliminiumfunctionalized complexes $[3,5,7-10] \mathrm{CF}_{3} \mathrm{SO}_{3}$ on the $\mathrm{A} 2780$ cell line is strongly improved in comparison to their aminocarbyne precursor $[\mathbf{1 a}] \mathrm{CF}_{3} \mathrm{SO}_{3}$, which is not active; ${ }^{7}$ a previous investigation pointed out the absence of activity of the ALK $^{\mathbf{A 1}}$ toward cancer cell lines. ${ }^{25}$
Mechanistic Studies. In order to shed light on the possible mechanism of action of the biofunctionalized diiron complexes, a series of complementary studies were performed. It was previously shown that the diiron vinyliminium structural motif induces ROS production, possibly associated with more than one mechanism: (1) monoelectron reduction of the complex favored by its net cationic charge; (2) fragmentation into a monoiron derivative and atomic iron; (3) rupture of the organometallic scaffold in aqueous medium releasing the two $\mathrm{Fe}^{+\mathrm{I}}$ centers which rapidly convert into iron(III) oxides. ${ }^{11-13,7}$ The aspirin complex $[4] \mathrm{CF}_{3} \mathrm{SO}_{3}$ and chlorambucil complex $[9] \mathrm{CF}_{3} \mathrm{SO}_{3}$ were selected as representative, strongly cytotoxic compounds for the evaluation of induced intracellular ROS production. Thus, fluorescence measurements were conducted using the DCFH-DA assay, exposing A2780 cells to [4]$\mathrm{CF}_{3} \mathrm{SO}_{3},[9] \mathrm{CF}_{3} \mathrm{SO}_{3}$, the reference drug cisplatin, or $\mathrm{H}_{2} \mathrm{O}_{2}$ as a positive control. Significant intracellular ROS levels were detected from $[4] \mathrm{CF}_{3} \mathrm{SO}_{3}$ and $[9] \mathrm{CF}_{3} \mathrm{SO}_{3}$, especially after ca. $20 \mathrm{~h}$, and progressively increasing up to $24 \mathrm{~h}$ (Figure 5). Remarkably, both diiron complexes elicited a ROS production 
Table 2. $\mathrm{IC}_{50}$ Calues $(\mu \mathrm{M})$ Determined for Compounds [210] $\mathrm{CF}_{3} \mathrm{SO}_{3}$, Cisplatin, $\left[2^{\prime}, 3^{\prime}\right] \mathrm{CF}_{3} \mathrm{SO}_{3},{ }^{11}[1 \mathrm{a}, \mathrm{b}] \mathrm{CF}_{3} \mathrm{SO}_{3},^{7}$ Aspirin, ${ }^{30}$ and Chlorambucil ${ }^{22 b}$ on Human Ovarian Carcinoma (A2780), Human Ovarian Carcinoma Cisplatin Resistant (A2780cisR), and Human Embryonic Kidney 293T (HEK 293T) Cell Lines after 72 h Exposure ${ }^{a}$

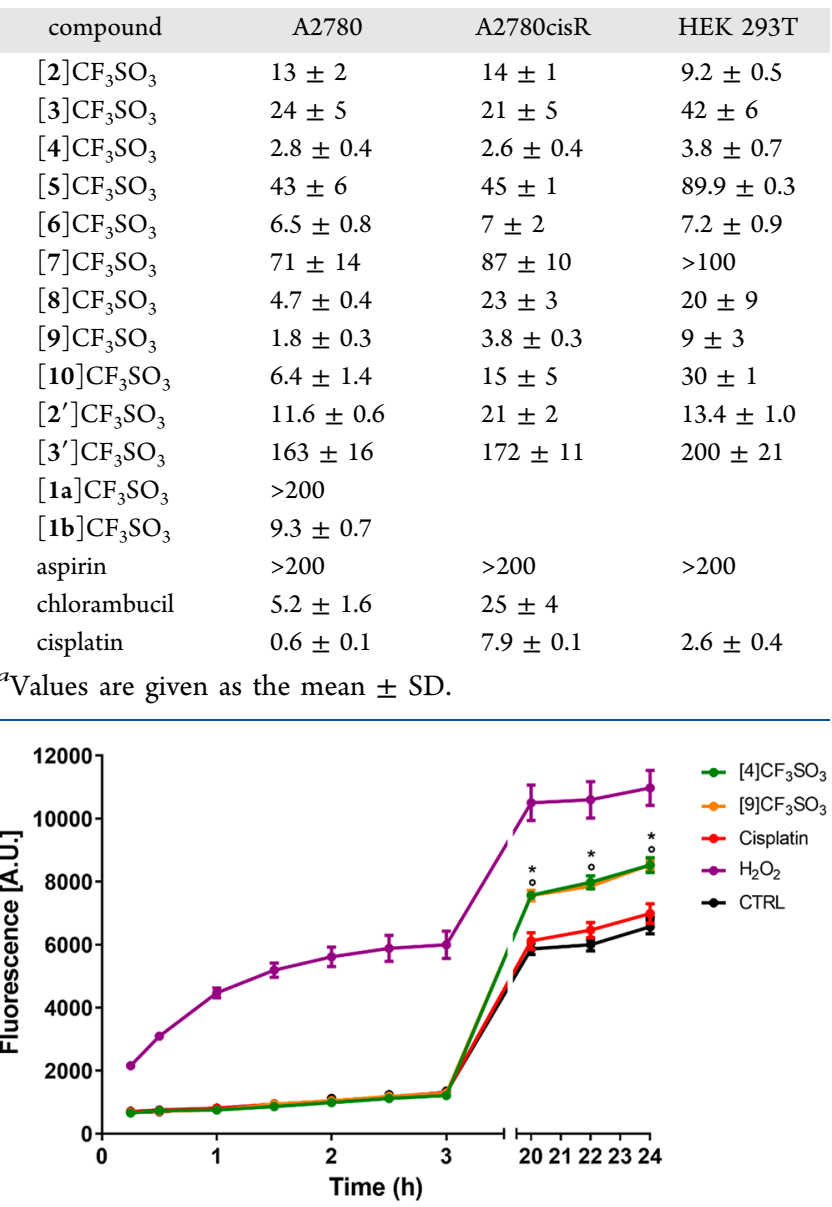

Figure 5. Fluorescence kinetic measurements of intracellular reactive oxygen species (ROS, $p<0.05$ ). A2780 cells were incubated for $24 \mathrm{~h}$ with $10 \mu \mathrm{M}$ of the iron compounds at $37^{\circ} \mathrm{C}$ and $5 \% \mathrm{CO}_{2}$.

higher than that recorded for $\mathrm{H}_{2} \mathrm{O}_{2}$. Thus, the incorporation of the bioactive fragments within the diiron structure does not reduce the ability of the complexes to interfere with cellular redox processes via ROS production, a phenomenon which may substantially contribute to the observed antiproliferative activity.

Next, the possible role of the bioactive fragment in the complexes was studied. COX-2 enzyme inhibition assays were performed on the aspirin compounds $[2-7] \mathrm{CF}_{3} \mathrm{SO}_{3}$ and also on a series of nonfunctionalized vinyliminium complexes as references, [11-14] $\mathrm{CF}_{3} \mathrm{SO}_{3}$ (Figure 4). In each case, the enzyme was treated with the complex and the residual enzyme activity was measured to determine the $\mathrm{IC}_{50}$ concentrations (Table 3). All diiron-aspirin conjugates exhibit significantly lower $\mathrm{IC}_{50}$ values in comparison to $[\mathbf{1 1 - 1 4}] \mathrm{CF}_{3} \mathrm{SO}_{3}$ and aspirin itself; this outcome indicates that the assembly of aspirin with the diiron framework provides a synergic effect in terms of COX-2 inhibition.

The ability of $[4] \mathrm{CF}_{3} \mathrm{SO}_{3}$ and $[9] \mathrm{CF}_{3} \mathrm{SO}_{3}$ to interact with natural DNA was studied using the ethidium bromide (EB)
Table 3. $\mathrm{IC}_{50}$ Values $(\mu \mathrm{M})$ Determined for Diiron Complexes and Aspirin in the Inhibition of COX-2 Enzyme $^{a}$

$\begin{array}{cc}\text { compound } & \mathrm{IC}_{50} \text { value }(\mu \mathrm{M}) \\ {[2] \mathrm{CF}_{3} \mathrm{SO}_{3}} & 84 \pm 2 \\ {[3] \mathrm{CF}_{3} \mathrm{SO}_{3}} & 71 \pm 1 \\ {[4] \mathrm{CF}_{3} \mathrm{SO}_{3}} & 30 \pm 3 \\ {[5] \mathrm{CF}_{3} \mathrm{SO}_{3}} & 10 \pm 2 \\ {[6] \mathrm{CF}_{3} \mathrm{SO}_{3}} & 66 \pm 2 \\ {[7] \mathrm{CF}_{3} \mathrm{SO}_{3}} & 20 \pm 2 \\ {[11] \mathrm{CF}_{3} \mathrm{SO}_{3}} & 541 \pm 55 \\ {[12] \mathrm{CF}_{3} \mathrm{SO}_{3}} & 506 \pm 15 \\ {[13] \mathrm{CF}_{3} \mathrm{SO}_{3}} & 629 \pm 49 \\ {[1 \mathbf{1 4}] \mathrm{CF}_{3} \mathrm{SO}_{3}} & 288 \pm 6 \\ \text { aspirin } & >1500^{31} \\ { }^{a} \text { Values are given as the mean } \pm \mathrm{SD} . & \end{array}$

exchange test (Figure 6), with the concentration of the complexes beingin the $1.5-124 \mu \mathrm{M}$ range for $[4] \mathrm{CF}_{3} \mathrm{SO}_{3}$ and

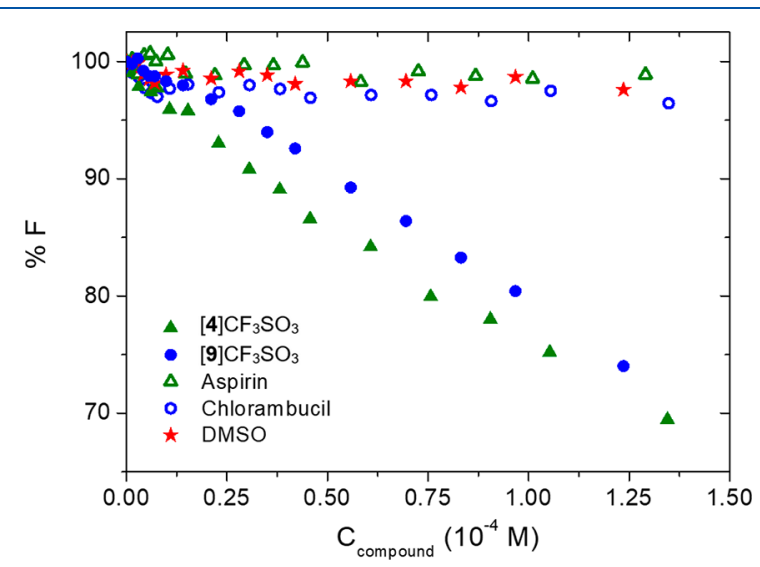

Figure 6. Ethidium bromide displacement tests for selected diiron vinyliminium complexes. Conditions: $C_{\mathrm{DNA}}=1.15 \times 10^{-4} \mathrm{M}, C_{\mathrm{EB}}=$ $5.60 \times 10^{-5} \mathrm{M}, \mathrm{NaCl} 0.1 \mathrm{M}, \mathrm{NaCac} 0.01 \mathrm{M}, \lambda_{\mathrm{ex}}=520 \mathrm{~nm}, \lambda_{\mathrm{em}}=595$ $\mathrm{nm}, \mathrm{T}=25^{\circ} \mathrm{C}$.

1.4-135 $\mu \mathrm{M}$ for $[9] \mathrm{CF}_{3} \mathrm{SO}_{3}$. Blank experiments were carried out with the two bioactive molecules and also with DMSO to check for solvent/dilution effects. The results indicate that both $[4] \mathrm{CF}_{3} \mathrm{SO}_{3}$ and $[9] \mathrm{CF}_{3} \mathrm{SO}_{3}$ are able to interact weakly with natural DNA, similarly to that previously described for nonfunctionalized diiron vinyliminium complexes. ${ }^{11}$ However, EB exchange titrations are suitable to recognize fast noncovalent binding events, but not subsequent slow covalent binding. Therefore, since chlorambucil is a DNA-alkylating agent, we studied the possible reaction of $[9] \mathrm{CF}_{3} \mathrm{SO}_{3}$ with the nucleotide guanosine 5 -monophosphate (disodium salt, $\mathrm{Na}_{2}$ [GMP]; see Figure 4) as a model for DNA binding. Complex $[9] \mathrm{CF}_{3} \mathrm{SO}_{3}$ was incubated with a $\mathrm{D}_{2} \mathrm{O} / \mathrm{CD}_{3} \mathrm{OD}$ mixture containing GMP for $24 \mathrm{~h}$ at $37^{\circ} \mathrm{C}$. A subsequent mass spectrometric analysis was indicative of almost complete conversion of $[\mathbf{9}]^{+}$into the neutral adduct $9^{\mathrm{GMP}}$ (Figure 4); the latter is best viewed as the result of the modification of the two ethyl chloride functions of $[9]^{+}$, one of the two being hydrolyzed and the other one undergoing chloride substitution by one imine function of $[\mathrm{GMP}]^{2-}$.

The interaction of $[4] \mathrm{CF}_{3} \mathrm{SO}_{3}$ and $[9] \mathrm{CF}_{3} \mathrm{SO}_{3}$ with bovine serum albumin (BSA) as a model protein was also explored. The addition of the metal complex to the protein in $\mathrm{pH}$ buffer 
solution ( $\mathrm{pH} 7.0$ buffer; $\mathrm{NaCl} \quad 0.1 \quad \mathrm{M}, \mathrm{NaCac} \quad 0.01 \quad \mathrm{M}$ ) produced a quenching of the intrinsic fluorescence emission of the latter. A data fit, according to the Stern-Volmer equation, ${ }^{11}$ provided quenching constants $\left(K_{\mathrm{SV}}\right)$ values equal to $c$ a. $3.4 \times 10^{4}$ for both systems, indicative that a binding event occurs (Figure S1). ${ }^{32}$ Spectral analysis ${ }^{33}$ collected during the titration revealed that a 1:1 stoichiometry model is adequate to describe the binding (Figure S2). The related Log $K$ values are $5.9 \pm 0.1$ for $[4] \mathrm{CF}_{3} \mathrm{SO}_{3} / \mathrm{BSA}$ and $6.5 \pm 0.1$ for $[9] \mathrm{CF}_{3} \mathrm{SO}_{3} / \mathrm{BSA}$ and suggest the occurrence of a reversible interaction, similarly to that previously found for nonfunctionalized diiron vinyliminium complexes. ${ }^{11}$ More precisely, the binding constant $\left(10^{6}\right)$ appears to be high enough to ensure adduct formation but also weak enough to release the complex once the biotarget is reached; this is assumed to be the optimal condition for BSA-driven transport and diffusion of a drug. ${ }^{34}$

\section{CONCLUSIONS}

Monoiron cyclopentadienyl complexes, and ferrocenes in particular, have aroused great interest due to their anticancer properties, while diiron complexes have been much less investigated despite the advantageous cooperative effects provided by two iron centers. The readily accessible $\left\{\mathrm{Fe}_{2} \mathrm{Cp}_{2}(\mathrm{CO})_{2}\right\}$ scaffold offers considerable opportunities for the construction of various bridging hydrocarbyl ligands, and here we show that bioactive carboxylic acids can be incorporated through an alkyne-insertion reaction. Aspirin (enzyme inhibitor) and chlorambucil (DNA alkylating agent) were selected as representative compounds to demonstrate the viability of the synthetic approach, but this may be extended to other bioactive molecules given the generality of the insertion reaction. ${ }^{10-12,29}$ The new complexes exhibit favorable characteristics in aqueous media, in that they are quite stable with a tendency to progressively release the bioactive fragment. The cytotoxicity ranges from moderate to the low-micromolar range, and complementary experiments reveal a possible multimodal action of the complexes, with the induction of intracellular ROS production playing a major role. The complexes manifest the specificity provided by the bioactive fragment, since experiments reveal the ability of chlorambucil complexes to alkylate DNA and that of aspirin complexes to inhibit COX-2 enzyme. In particular, diiron-chlorambucil conjugates display a cytotoxicity profile more comparable to that of cisplatin. The versatility of the synthetic method and the broad structural variability provided by the diiron core allows fine-tuning of physicochemical properties of the complexes, which is conducive to the future development of optimal iron drug candidates.

\section{EXPERIMENTAL SECTION}

Synthesis and Characterization of Compounds. General Details. Organic reactants were purchased from TCI Europe or Merck and were of the highest purity available, while solvents were purchased from Merck (petroleum ether, bp 40-60 ${ }^{\circ} \mathrm{C}$ ). The compounds $\mathbf{A L K}^{\mathrm{A} \mathbf{1}},{ }^{25,35}\left[\mathrm{Fe}_{2} \mathrm{Cp}_{2}(\mathrm{CO})_{2}(\mu\right.$-CO $)\{\mu$-CNMe(R)\}]$\mathrm{CF}_{3} \mathrm{SO}_{3}\left(\mathrm{R}=\mathrm{Me}, \quad[\mathbf{1} \mathrm{a}] \mathrm{CF}_{3} \mathrm{SO}_{3} ; \mathrm{R}=\mathrm{Xyl}=2,6-\mathrm{C}_{6} \mathrm{H}_{3} \mathrm{Me}_{2}\right.$, $\left.[\mathbf{1 b}] \mathrm{CF}_{3} \mathrm{SO}_{3}\right),{ }^{28}[\mathbf{1 1}] \mathrm{CF}_{3} \mathrm{SO}_{3}{ }^{36}[\mathbf{1 2}] \mathrm{CF}_{3} \mathrm{SO}_{3}$, and $[\mathbf{1 4}] \mathrm{CF}_{3} \mathrm{SO}_{3}{ }^{11}$ and $[13] \mathrm{CF}_{3} \mathrm{SO}_{3}{ }^{37}$ were prepared according to the literature. The synthesis of alkynes was carried out under an $\mathrm{N}_{2}$ atmosphere using standard Schlenk techniques, and solvents were distilled before use from the appropriate drying agents under $\mathrm{N}_{2}$; all other operations were conducted in air. Once isolated, products were stored in air. Separations were carried out on columns of silica (Merck), deactivated alumina (Merck, 4\% w/w water), or Celite (Fluka, 512 Medium). Infrared spectra of solutions were recorded on a PerkinElmer Spectrum 100 FT-IR spectrometer with a $\mathrm{CaF}_{2}$ liquid transmission cell $\left(2300-1500 \mathrm{~cm}^{-1}\right.$ range) or on solid samples at 298 $\mathrm{K}$ on a PerkinElmer FT-IR spectrometer, equipped with a UATR sampling accessory. UV-vis spectra were recorded on an Ultraspec 2100 Pro spectrophotometer. IR and UV-vis spectra were processed with Spectragryph software. ${ }^{38}$ NMR spectra were recorded at $298 \mathrm{~K}$ on a Bruker Avance II DRX400 instrument equipped with a BBFO broad-band probe. Chemical shifts (expressed in parts per million) are referenced to the residual solvent peaks ${ }^{39}\left({ }^{1} \mathrm{H},{ }^{13} \mathrm{C}\right)$. NMR spectra were assigned with the assistance of ${ }^{1} \mathrm{H}-{ }^{13} \mathrm{C}$ ( $g s$-HSQC and $g s$ HMBC) correlation experiments. ${ }^{40}$ NMR signals due to secondary isomeric forms (where it has been possible to detect them) are italicized. Elemental analyses were performed on a Vario MICRO cube instrument (Elementar). HPLC-MS analyses were performed with a HPLC 1200 Infinity, coupled with a quadrupole time of flight tandem mass spectrometer 6530 Infinity Q-ToF detector by a Jet Stream ESI interface (Agilent Technologies, USA); the data were processed with Mass Hunter Qualitative Analysis software.

Synthesis and Characterization of Diiron Complexes. General Procedure. A solution of $[\mathbf{1} \mathbf{a}, \mathbf{b}] \mathrm{CF}_{3} \mathrm{SO}_{3}$ (ca. $0.5 \mathrm{mmol}$ ) in $\mathrm{MeCN}$ (ca. $10 \mathrm{~mL}$ ) was treated with $\mathrm{Me}_{3} \mathrm{NO}$ (1.3 equiv). The resulting mixture was stirred for $1 \mathrm{~h}$, during which time progressive color darkening occurred. The complete conversion of the starting material into the corresponding acetonitrile adduct $\left[\mathrm{Fe}_{2} \mathrm{Cp}_{2}(\mathrm{CO})(\mu\right.$ $\mathrm{CO})(\mathrm{NCMe})\{\mu-\mathrm{CN}(\mathrm{Me})(\mathrm{R})\}] \mathrm{CF}_{3} \mathrm{SO}_{3}{ }^{41}$ was checked by IR spectroscopy. The volatiles were removed under vacuum to afford a dark brown residue that was dissolved in dichloromethane (ca. $20 \mathrm{~mL}$ ) and treated with the appropriate alkyne (ca. 1.3 equiv). The mixture was stirred at room temperature for $48 \mathrm{~h}$, and then it was filtered through Celite. The volatiles were evaporated from the filtered solution under reduced pressure, and the residue was repeatedly washed with diethyl ether and finally dried under vacuum.

$\left[\mathrm{Fe}_{2} \mathrm{Cp}_{2}(\mathrm{CO})(\mu-\mathrm{CO})\left\{\mu-\eta^{1}: \eta^{3}-\mathrm{C}_{\gamma}\left(\mathrm{CH}_{2} \mathrm{OC}(=\mathrm{O}) \mathrm{C}_{6} \mathrm{H}_{4} \mathrm{OC}(=\mathrm{O}) \mathrm{Me}\right)-\right.\right.$ $\left.\left.\mathrm{C}_{\beta} \mathrm{HC}_{\alpha} \mathrm{NMe}(\mathrm{Xyl})\right\}\right] \mathrm{CF}_{3} \mathrm{SO}_{3}\left([2] \mathrm{CF}_{3} \mathrm{SO}_{3}\right)$ (Chart 1). This compound was

Chart 1. Structure of $[2]^{+}$

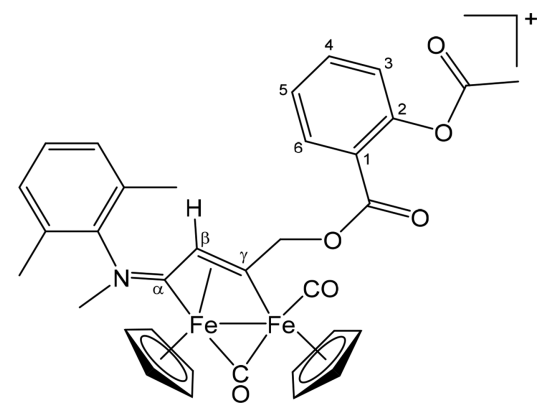

obtained from $[\mathbf{1} \mathbf{b}] \mathrm{CF}_{3} \mathrm{SO}_{3}$ and $\mathbf{A L K}^{\mathrm{A} \mathbf{1}}$ : brown solid, yield 52\%. Anal. Calcd for $\mathrm{C}_{35} \mathrm{H}_{32} \mathrm{~F}_{3} \mathrm{Fe}_{2} \mathrm{NO}_{9} \mathrm{~S}$ : C, 51.81; H, 3.98; N, 1.73; S, 3.95. Found: C, 51.70; H, 3.88; N, 1.83; S, 4.04. IR $\left(\mathrm{CH}_{2} \mathrm{Cl}_{2}\right): \tilde{\nu} / \mathrm{cm}^{-1}$ $2007 \mathrm{vs}(\mathrm{CO}), 1820 \mathrm{~s}\left(\mu\right.$-CO), 1766s $(\mathrm{MeC}=\mathrm{O}), 1727 \mathrm{~s}\left(\mathrm{C}_{6} \mathrm{H}_{4} \mathrm{C}=\right.$ $O), 1634 \mathrm{~m}\left(\mathrm{C}_{\beta} \mathrm{C}_{\alpha} \mathrm{N}\right), 1607 \mathrm{~m}\left(\mathrm{C}-\mathrm{C}_{\text {arom }}\right) .{ }^{1} \mathrm{H}$ NMR $\left(\mathrm{CDCl}_{3}\right): \delta / \mathrm{ppm}$ 8.05-6.90 (m, $\left.7 \mathrm{H}, \mathrm{C}_{6} \mathrm{H}_{4}+\mathrm{C}_{6} \mathrm{H}_{3}\right) ; 6.81,6.53\left(\mathrm{~d},{ }^{2} \mathrm{~J}=15.1 \mathrm{~Hz}, 2 \mathrm{H}\right.$, $\left.\mathrm{CH}_{2}\right)$; 5.53, 5.24, 5.03, $4.45(\mathrm{~s}, 10 \mathrm{H}, \mathrm{Cp}) ; 4.38\left(\mathrm{~s}, 1 \mathrm{H}, \mathrm{C}_{\beta} \mathrm{H}\right) ; 4.20$, $2.70(\mathrm{~s}, 3 \mathrm{H}, \mathrm{NMe}) ; 2.21,2.20(\mathrm{~s}, 3 \mathrm{H}, \mathrm{O}=\mathrm{CMe}) ; 2.18,2.14,2.07$, $1.80\left(\mathrm{~s}, 6 \mathrm{H}, \mathrm{C}_{6} \mathrm{H}_{3} M e_{2}\right) . E / Z$ ratio ca. $2 .{ }^{13} \mathrm{C}\left\{{ }^{1} \mathrm{H}\right\}$ NMR (acetone- $\left.d_{6}\right)$ : $\delta / \mathrm{ppm} 252.7\left(\mu\right.$-CO); $232.4\left(\mathrm{C}_{\alpha}\right) ; 210.0(\mathrm{CO}) ; 200.7\left(\mathrm{C}_{\gamma}\right) ; 169.0$ $(\mathrm{O}=\mathrm{CMe}) ; 163.5\left(\mathrm{C}_{6} \mathrm{H}_{4} \mathrm{C}=\mathrm{O}\right) ; 151.1\left(\mathrm{C}^{2}\right) ; 145.2,131.8,131.3$ (ipso- $\left.\mathrm{C}_{6} \mathrm{H}_{3}\right) ; 134.5,131.2,129.6,129.4,129.3,126.3,124.3\left(\mathrm{C}_{6} \mathrm{H}_{4}+\right.$ $\left.\mathrm{C}_{6} \mathrm{H}_{3}\right)$; $123.2\left(\mathrm{C}^{1}\right)$; 90.8, 88.1 (Cp); $76.3\left(\mathrm{CH}_{2}\right) ; 48.6\left(\mathrm{C}_{\beta}\right) ; 45.7$ $(\mathrm{NMe}) ; 20.0(\mathrm{O}=\mathrm{CMe}) ; 17.1,16.5\left(\mathrm{C}_{6} \mathrm{H}_{3} \mathrm{Me} 2\right)$. Crystals of 2 suitable for X-ray analysis were obtained by slow evaporation of the solvent from a methanol solution.

$\left[\mathrm{Fe}_{2} \mathrm{Cp}_{2}(\mathrm{CO})(\mu-\mathrm{CO})\left\{\mu-\eta^{7}: \eta^{3}-\mathrm{C}_{\gamma}\left(3-\mathrm{C}_{6} \mathrm{H}_{4} \mathrm{OC}(=\mathrm{O}) \mathrm{C}_{6} \mathrm{H}_{4} \mathrm{OC}(=\mathrm{O}) \mathrm{Me}\right)-\right.\right.$ $\left.\left.\mathrm{C}_{\beta} \mathrm{HC}_{\alpha} \mathrm{NMe}_{2}\right\}\right] \mathrm{CF}_{3} \mathrm{SO}_{3} \quad\left([3] \mathrm{CF}_{3} \mathrm{SO}_{3}\right)$ (Chart 2). This compound was 
Chart 2. Structure of $[3]^{+}$

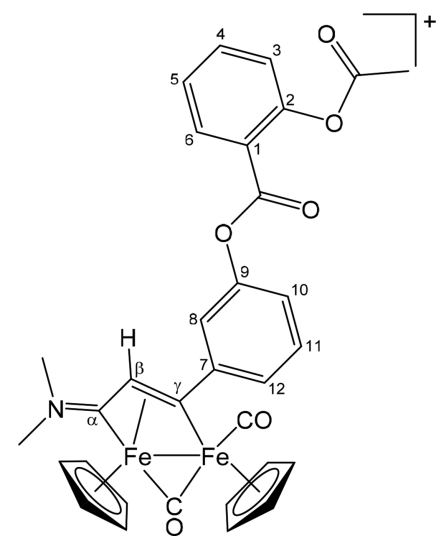

obtained from [1 $1 \mathrm{a}] \mathrm{CF}_{3} \mathrm{SO}_{3}$ and $\mathrm{ALK}^{\mathrm{A} 2}$ : brown solid, yield $48 \%$. Anal. Calcd for $\mathrm{C}_{33} \mathrm{H}_{28} \mathrm{~F}_{3} \mathrm{Fe}_{2} \mathrm{NO}_{9} \mathrm{~S}$ : C, 50.60; H, 3.60; N, 1.79; S, 4.09 . Found: C, 50.45; H, 3.65; N, 1.83; S, 4.03. IR $\left(\mathrm{CH}_{2} \mathrm{Cl}_{2}\right): \tilde{\nu} / \mathrm{cm}^{-1}$ 1993vs (CO), 1809s $\left(\mu\right.$-CO), $1767 \mathrm{~m}(\mathrm{MeC}=O), 1743 \mathrm{~s}\left(\mathrm{C}_{6} \mathrm{H}_{4} \mathrm{C}=\right.$ $O), 1692 \mathrm{~m}\left(\mathrm{C}_{\beta} \mathrm{C}_{\alpha} \mathrm{N}\right), 1607 \mathrm{w}\left(\mathrm{C}-\mathrm{C}_{\text {arom }}\right), 1577 \mathrm{w}\left(\mathrm{C}-\mathrm{C}_{\text {arom }}\right) .{ }^{1} \mathrm{H}$ NMR $\left(\mathrm{CDCl}_{3}\right): \delta / \mathrm{ppm} 8.28\left(\mathrm{dd},{ }^{3} J_{\mathrm{H} 3-\mathrm{H} 4}=7.8 \mathrm{~Hz},{ }^{4} J_{\mathrm{H} 3-\mathrm{H} 5}=1.4 \mathrm{~Hz}\right.$, $\left.1 \mathrm{H}, \mathrm{H}^{3}\right)$; $7.71\left(\mathrm{t},{ }^{3} \mathrm{~J}=7.6 \mathrm{~Hz}, 1 \mathrm{H}, \mathrm{H}^{5}\right) ; 7.58\left(\mathrm{t},{ }^{3} \mathrm{~J}=8.1 \mathrm{~Hz}, 1 \mathrm{H}, \mathrm{H}^{4}\right)$; 7.51, 7.49-7.41, 7.25-7.18 (m, $\left.5 \mathrm{H}, \mathrm{H}^{6}+\mathrm{H}^{8}+\mathrm{H}^{10}+\mathrm{H}^{11}+\mathrm{H}^{12}\right)$; 5.25, 5.02 (s, $10 \mathrm{H}, \mathrm{Cp}) ; 4.84\left(\mathrm{~s}, 1 \mathrm{H}, \mathrm{C}_{\beta} \mathrm{H}\right) ; 3.96,3.43(\mathrm{~s}, 6 \mathrm{H}$, $\left.\mathrm{NMe}_{2}\right) ; 2.30(\mathrm{~s}, 3 \mathrm{H}, \mathrm{O}=\mathrm{CMe}) .{ }^{13} \mathrm{C}\left\{{ }^{1} \mathrm{H}\right\} \operatorname{NMR}\left(\mathrm{CDCl}_{3}\right): \delta / \mathrm{ppm}$ 255.7 ( $\mu$-CO); $224.5\left(\mathrm{C}_{\alpha}\right) ; 209.4(\mathrm{CO}) ; 201.3\left(\mathrm{C}_{\gamma}\right) ; 169.9(\mathrm{O}=$ $\mathrm{CMe})$; $163.5\left(\mathrm{C}_{6} \mathrm{H}_{4} \mathrm{C}=\mathrm{O}\right)$; $157.0\left(\mathrm{C}^{7}\right)$; $150.9,150.3\left(\mathrm{C}^{2}+\mathrm{C}^{9}\right)$; 134.9, 132.2, 130.1, 126.4, 124.5, 123.8, 121.0, $120.1\left(\mathrm{C}_{6} \mathrm{H}_{4}\right) ; 122.5$ $\left(\mathrm{C}^{1}\right)$; 91.3, $87.8(\mathrm{Cp})$; $52.9\left(\mathrm{C}_{\beta}\right)$; 51.7, $44.6\left(\mathrm{NMe}_{2}\right) ; 21.2(\mathrm{O}=$ $\mathrm{CMe}$ ).

$\left[\mathrm{Fe}_{2} \mathrm{Cp}_{2}(\mathrm{CO})(\mu-\mathrm{CO})\left\{\mu-\eta^{7}: \eta^{3}-\mathrm{C}_{\gamma}\left(3-\mathrm{C}_{6} \mathrm{H}_{4} \mathrm{OC}(=\mathrm{O}) \mathrm{C}_{6} \mathrm{H}_{4} \mathrm{OC}(=\mathrm{O}) \mathrm{Me}\right)-\right.\right.$ $\left.\left.\mathrm{C}_{\beta} \mathrm{HC}_{\alpha} \mathrm{NMe}(\mathrm{Xyl})\right\}\right] \mathrm{CF}_{3} \mathrm{SO}_{3}\left([4] \mathrm{CF}_{3} \mathrm{SO}_{3}\right)$ (Chart 3). This compound was

\section{Chart 3. Structure of $[4]^{+}$}

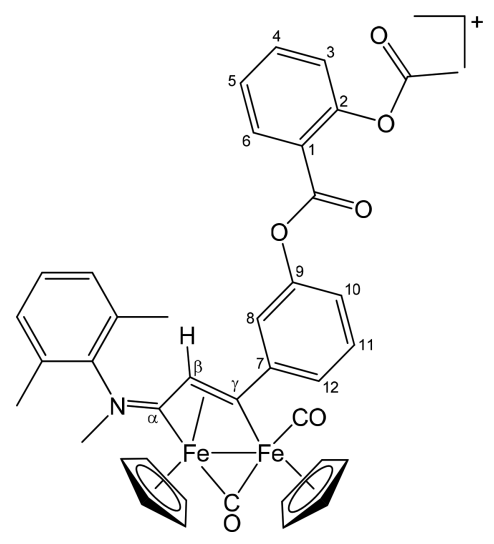

obtained from $[\mathbf{1 b}] \mathrm{CF}_{3} \mathrm{SO}_{3}$ and $\mathrm{ALK}^{\mathrm{A} 2}$ : brown solid, yield $86 \%$. Anal. Calcd. for $\mathrm{C}_{40} \mathrm{H}_{34} \mathrm{~F}_{3} \mathrm{Fe}_{2} \mathrm{NO}_{9} \mathrm{~S}$ : C, 55.00; H, 3.924; N, 1.60; S, 3.67. Found: C, 54.87; H, 3.95; N, 1.55; S, 3.52. IR $\left(\mathrm{CH}_{2} \mathrm{Cl}_{2}\right): \tilde{\nu} / \mathrm{cm}^{-1}$ 2004vs (CO), 1819s ( $\mu$-CO), 1768m $(\mathrm{MeC}=\mathrm{O}), 1744 \mathrm{~s}\left(\mathrm{C}_{6} \mathrm{H}_{4} \mathrm{C}=\right.$ $O), 1631 \mathrm{~m}\left(\mathrm{C}_{\beta} \mathrm{C}_{\alpha} \mathrm{N}\right), 1607 \mathrm{w}\left(\mathrm{C}-\mathrm{C}_{\text {arom }}\right), 1578 \mathrm{w}\left(\mathrm{C}-\mathrm{C}_{\text {arom }}\right) .{ }^{1} \mathrm{H}$ NMR (acetone- $\left.d_{6}\right): \delta / \mathrm{ppm} 8.23,7.79,7.65-7.00\left(\mathrm{~m}, 11 \mathrm{H}, \mathrm{C}_{6} \mathrm{H}_{4}+\right.$ $\left.\mathrm{C}_{6} \mathrm{H}_{3}\right) ; 5.70,5.47$ (s, $\left.10 \mathrm{H}, \mathrm{Cp}\right) ; 4.44$ (br s, $\left.4 \mathrm{H}, \mathrm{NMe}+\mathrm{C}_{\beta} \mathrm{H}\right) ; 2.37$ $(\mathrm{s}, 3 \mathrm{H}, \mathrm{O}=\mathrm{CMe}) ; 2.25,1.89\left(\mathrm{~s}, 6 \mathrm{H}, \mathrm{C}_{6} \mathrm{H}_{3} \mathrm{Me}_{2}\right) .{ }^{13} \mathrm{C}\left\{{ }^{1} \mathrm{H}\right\} \mathrm{NMR}$ (acetone- $\left.d_{6}\right): \delta / \mathrm{ppm} 253.1\left(\mu\right.$-CO); $232.1\left(\mathrm{C}_{\alpha}\right) ; 210.1(\mathrm{CO}) ; 169.0$ $(\mathrm{O}=\mathrm{CMe}) ; 163.1\left(\mathrm{C}_{6} \mathrm{H}_{4} \mathrm{C}=\mathrm{O}\right) ; 157.2\left(\mathrm{C}^{7}\right) ; 151.1,150.4\left(\mathrm{C}^{2}+\mathrm{C}^{9}\right)$; 145.4, 132.0, 131.3 (ipso- $\left.\mathrm{C}_{6} \mathrm{H}_{3}\right) ; 134.9,131.8,129.7,129.6,129.3$, 129.3, 126.2, 124.1, 124.1, 120.8, $120.1\left(\mathrm{C}_{6} \mathrm{H}_{4}+\mathrm{C}_{6} \mathrm{H}_{3}\right) ; 122.9\left(\mathrm{C}^{1}\right)$; 92.5, 88.2 (Cp); $53.8\left(\mathrm{C}_{\beta}\right)$; $45.5(\mathrm{NMe}) ; 20.2(\mathrm{O}=\mathrm{CMe})$; 17.3, 16.6 $\left(\mathrm{C}_{6} \mathrm{H}_{3} \mathrm{Me}_{2}\right) \cdot \mathrm{C}_{\gamma}$ overlapped with solvent signal.
$\left[\mathrm{Fe}_{2} \mathrm{Cp}_{2}(\mathrm{CO})(\mu-\mathrm{CO})\left\{\mu-\eta^{1}: \eta^{3}-\mathrm{C}_{\gamma}\left(3-\mathrm{C}_{6} \mathrm{H}_{4} \mathrm{NHC}(=\mathrm{O}) \mathrm{C}_{6} \mathrm{H}_{4} \mathrm{OC}(=\mathrm{O}) \mathrm{Me}\right)-\right.\right.$ $\left.\left.\mathrm{C}_{\beta} \mathrm{HC}_{\alpha} \mathrm{NMe}_{2}\right\}\right] \mathrm{CF}_{3} \mathrm{SO}_{3}\left([5] \mathrm{CF}_{3} \mathrm{SO}_{3}\right)$ (Chart 4). This compound was

Chart 4. Structure of $[5]^{+}$

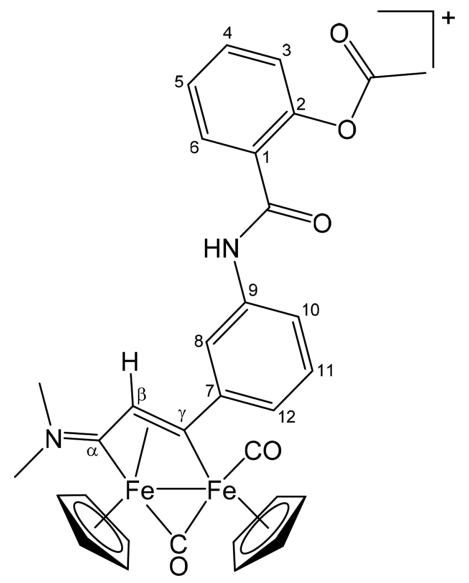

obtained from [1a $] \mathrm{CF}_{3} \mathrm{SO}_{3}$ and $\mathrm{ALK}^{\mathrm{A} 3}$ : brown solid, yield 96\%. Anal. Calcd for $\mathrm{C}_{33} \mathrm{H}_{29} \mathrm{~F}_{3} \mathrm{Fe}_{2} \mathrm{~N}_{2} \mathrm{O}_{8} \mathrm{~S}$ : C, 50.66; H, 3.74; N, 3.58; S, 4.10. Found: C, 50.74; H, 3.62; N, 3.68; S, 4.00. IR $\left(\mathrm{CH}_{2} \mathrm{Cl}_{2}\right): \tilde{\nu} / \mathrm{cm}^{-1}$ 1991vs (CO), 1807s $\left(\mu\right.$-CO), 1770m $(\mathrm{MeC}=O), 1678 \mathrm{~s}\left(\mathrm{C}_{\beta} \mathrm{C}_{\alpha} \mathrm{N}+\right.$ $\mathrm{NC}=O), 1604 \mathrm{~m}\left(\mathrm{C}-\mathrm{C}_{\text {arom }}\right), 1582 \mathrm{~m}\left(\mathrm{C}-\mathrm{C}_{\text {arom }}\right), 1537 \mathrm{~s} .{ }^{1} \mathrm{H}$ NMR (acetone- $\left.\mathrm{d}_{6}\right): \delta / \mathrm{ppm} 9.75(\mathrm{~s}, 1 \mathrm{H}, \mathrm{NH}) ; 8.70,7.90-7.20(\mathrm{~m}, 8 \mathrm{H}$, $\left.\mathrm{C}_{6} \mathrm{H}_{4}\right)$; 5.45, $5.31(\mathrm{~s}, 10 \mathrm{H}, \mathrm{Cp}) ; 4.74\left(\mathrm{~s}, 1 \mathrm{H}, \mathrm{C}_{\beta} \mathrm{H}\right)$; 4.07, $3.48(\mathrm{~s}, 6$ $\left.\mathrm{H}, \mathrm{NMe}_{2}\right) ; 2.23(\mathrm{~s}, 3 \mathrm{H}, \mathrm{O}=\mathrm{CMe}) .{ }^{13} \mathrm{C}$ NMR (acetone- $\left.d_{6}\right): \delta / \mathrm{ppm}$ $255.8\left(\mu\right.$-CO); $224.9\left(\mathrm{C}_{\alpha}\right) ; 210.0(\mathrm{CO}) ; 203.6\left(\mathrm{C}_{\gamma}\right) ; 168.7(\mathrm{O}=$ $\mathrm{Me}) ; 164.8(\mathrm{NC}=\mathrm{O}) ; 156.7\left(\mathrm{C}^{7}\right) ; 148.7\left(\mathrm{C}^{2}\right) ; 139.1\left(\mathrm{C}^{9}\right) ; 129.6$ $\left(C^{1}\right) ; 131.8,129.1,128.8,125.9,123.4,122.4,119.2,118.2\left(\mathrm{C}_{6} \mathrm{H}_{4}\right)$; 91.7, $87.9(\mathrm{Cp}) ; 53.0\left(\mathrm{C}_{\beta}\right) ; 50.9,44.2\left(\mathrm{NMe}_{2}\right) ; 20.2(\mathrm{O}=\mathrm{CMe})$.

$\left[\mathrm{Fe}_{2} \mathrm{Cp}_{2}(\mathrm{CO})(\mu-\mathrm{CO})\left\{\mu-\eta \eta^{7}: \eta^{3}-\mathrm{C}_{\gamma}\left(3-\mathrm{C}_{6} \mathrm{H}_{4} \mathrm{NHC}(=\mathrm{O}) \mathrm{C}_{6} \mathrm{H}_{4} \mathrm{OC}(=\mathrm{O}) \mathrm{Me}\right)-\right.\right.$ $\left.\left.\mathrm{C}_{\beta} \mathrm{HC}_{\alpha} \mathrm{NMe}(\mathrm{Xyl})\right\}\right] \mathrm{CF}_{3} \mathrm{SO}_{3}\left([6] \mathrm{CF}_{3} \mathrm{SO}_{3}\right)$ (Chart 5). This compound was

Chart 5. Structure of $[6]^{+}$

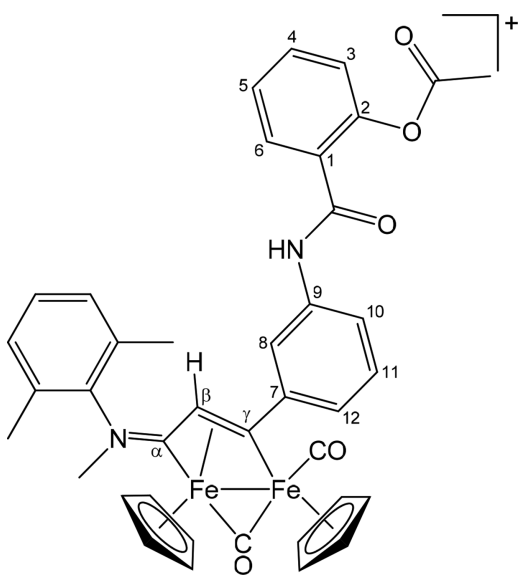

obtained from $[\mathbf{1 b}] \mathrm{CF}_{3} \mathrm{SO}_{3}$ and $\mathrm{ALK}^{\mathrm{A} 3}$ : brown solid, yield 95\%. Anal. Calcd. for $\mathrm{C}_{40} \mathrm{H}_{35} \mathrm{~F}_{3} \mathrm{Fe}_{2} \mathrm{~N}_{2} \mathrm{O}_{8} \mathrm{~S}$ : C, 55.07; H, 4.04; N, 3.21; S, 3.68. Found: C, 55.25; H, 4.03; N, 3.25; S, 3.62. IR $\left(\mathrm{CH}_{2} \mathrm{Cl}_{2}\right): \tilde{\nu} / \mathrm{cm}^{-1}$ 2003vs (CO), 1816s ( $\mu$-CO), 1771w $(\mathrm{MeC}=O), 1678 \mathrm{~m}(\mathrm{NC}=O)$, $1628 \mathrm{~m}\left(\mathrm{C}_{\beta} \mathrm{C}_{\alpha} \mathrm{N}\right), 1605 \mathrm{~m}\left(\mathrm{C}-\mathrm{C}_{\text {arom }}\right), 1583 \mathrm{~m}\left(\mathrm{C}-\mathrm{C}_{\text {arom }}\right), 1535 \mathrm{~s} .{ }^{1} \mathrm{H}$ NMR (acetone- $\left.d_{6}\right): \delta /$ ppm $9.74(\mathrm{~s}, 1 \mathrm{H}, \mathrm{NH}) ; 8.40\left(\mathrm{~s}, 1 \mathrm{H}, \mathrm{H}^{8}\right)$; 7.68, 7.44, $7.15\left(\mathrm{~m}, 3 \mathrm{H}, \mathrm{H}^{10}+\mathrm{H}^{11}+\mathrm{H}^{12}\right) ; 7.82,7.59,7.40,7.24(\mathrm{~m}$, $\left.4 \mathrm{H}, \mathrm{H}^{3}+\mathrm{H}^{4}+\mathrm{H}^{5}+\mathrm{H}^{6}\right) ; 7.26,7.19,7.10\left(\mathrm{~m}, 3 \mathrm{H}, \mathrm{C}_{6} \mathrm{H}_{3}\right) ; 5.69,5.43$, 5.38, 5.09 (s, $10 \mathrm{H}, \mathrm{Cp}) ; 4.43,2.62(\mathrm{~s}, 3 \mathrm{H}, \mathrm{NMe}) ; 4.36(\mathrm{~s}, 1 \mathrm{H}$, $\left.\mathrm{C}_{\beta} \mathrm{H}\right) ; 2.36,1.89\left(\mathrm{~s}, 6 \mathrm{H}, \mathrm{C}_{6} \mathrm{H}_{3} M e_{2}\right) ; 2.21$ (s, $\left.3 \mathrm{H}, \mathrm{O}=\mathrm{CMe}\right) . E / Z$ ratio $9 .{ }^{13} \mathrm{C}$ NMR (acetone- $\left.d_{6}\right): \delta / \mathrm{ppm} 253.4\left(\mu\right.$-CO); $232.2\left(\mathrm{C}_{\alpha}\right)$; $210.3(\mathrm{CO}) ; 207.8\left(\mathrm{C}_{\gamma}\right) ; 168.6(\mathrm{O}=\mathrm{CMe}) ; 164.7(\mathrm{NC}=\mathrm{O}) ; 156.4$ $\left(C^{7}\right)$; $148.7\left(C^{2}\right)$; 145.5, 132.0, $131.3\left(\right.$ ipso- $\left.\mathrm{C}_{6} \mathrm{H}_{3}\right)$; $139.0\left(\mathrm{C}^{9}\right)$; 129.6, 
129.3, $129.1\left(\mathrm{C}_{6} \mathrm{H}_{3}\right) ; 129.1\left(\mathrm{C}^{1}\right) ; 131.8,129.3,125.9,123.4\left(\mathrm{C}^{3}+\mathrm{C}^{4}\right.$ $\left.+C^{5}+C^{6}\right)$; 128.8, 122.0, 118.2 $\left(C^{10}+C^{11}+C^{12}\right) ; 118.2\left(C^{8}\right) ; 92.5$, 92.4, 88.2, 88.0 (Cp); $53.8\left(\mathrm{C}_{\beta}\right)$; $45.5(\mathrm{NMe}) ; 20.2(\mathrm{O}=\mathrm{CMe}) ; 17.3$, $16.6\left(\mathrm{C}_{6} \mathrm{H}_{3} \mathrm{Me}_{2}\right)$.

$\left[\mathrm{Fe}_{2} \mathrm{C} p_{2}(\mathrm{CO})(\mu-\mathrm{CO})\left\{\mu-\eta^{1}: \eta^{3}-\mathrm{C}_{2}\left(4-\mathrm{C}_{6} \mathrm{H}_{4} \mathrm{NHC}(=\mathrm{O}) \mathrm{C}_{6} \mathrm{H}_{4} \mathrm{OC}(=\mathrm{O}) \mathrm{Me}\right)-\right.\right.$ $\left.\left.\mathrm{C}_{\beta} \mathrm{HC}_{\alpha} \mathrm{NMe}_{2}\right\}\right] \mathrm{CF}_{3} \mathrm{SO}_{3}\left([\mathrm{7}] \mathrm{CF}_{3} \mathrm{SO}_{3}\right)$ (Chart 6). This compound was

Chart 6. Structure of $[7]^{+}$

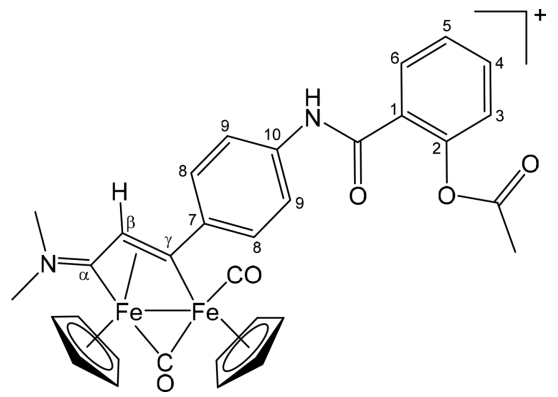

obtained from $[\mathbf{1 a}] \mathrm{CF}_{3} \mathrm{SO}_{3}$ and $\mathrm{ALK}^{\mathrm{A} 4}$ : brown solid, yield $81 \%$. Anal. Calcd for $\mathrm{C}_{33} \mathrm{H}_{29} \mathrm{~F}_{3} \mathrm{Fe}_{2} \mathrm{~N}_{2} \mathrm{O}_{8} \mathrm{~S}$ : C, 50.66; H, 3.74; N, 3.58; S, 4.10 . Found: C, 50.52; H, 3.78; N, 3.51; S, 4.16. IR $\left(\mathrm{CH}_{2} \mathrm{Cl}_{2}\right): \tilde{\nu} / \mathrm{cm}^{-1}$ 1991vs (CO), 1807s $\left(\mu\right.$-CO), 1773w $(\mathrm{MeC}=O), 1681 \mathrm{~s}\left(\mathrm{C}_{\beta} \mathrm{C}_{\alpha} \mathrm{N}+\right.$ $\mathrm{NC}=O), 1604 \mathrm{~m}\left(\mathrm{C}-\mathrm{C}_{\text {arom }}\right), 1589 \mathrm{~m}\left(\mathrm{C}-\mathrm{C}_{\text {arom }}\right), 1518 \mathrm{~s} .{ }^{1} \mathrm{H}$ NMR (acetone- $\left.d_{6}\right): \delta / \mathrm{ppm} 9.65(\mathrm{~s}, 1 \mathrm{H}, \mathrm{NH}) ; 7.98,7.95-7.70,7.60,7.42$, $7.26\left(\mathrm{~m}, 8 \mathrm{H}, \mathrm{C}_{6} \mathrm{H}_{4}\right)$; 5.41, $5.30(\mathrm{~s}, 10 \mathrm{H}, \mathrm{Cp})$; $4.66\left(\mathrm{~s}, 1 \mathrm{H}, \mathrm{C}_{\beta} \mathrm{H}\right)$; 4.05, $3.47\left(\mathrm{~s}, 6 \mathrm{H}, \mathrm{NMe}_{2}\right) ; 2.29(\mathrm{~s}, 3 \mathrm{H}, \mathrm{O}=\mathrm{CMe}) .{ }^{13} \mathrm{C}\left\{{ }^{1} \mathrm{H}\right\} \mathrm{NMR}$ (acetone- $\left.d_{6}\right): \delta / \mathrm{ppm} 256.0\left(\mu\right.$-CO); $225.3\left(\mathrm{C}_{\alpha}\right) ; 210.1(\mathrm{CO}) ; 203.3$ $\left(\mathrm{C}_{\gamma}\right) ; 168.6(\mathrm{O}=\mathrm{CMe}) ; 152.3(\mathrm{NC}=\mathrm{O}) ; 148.7,138.4,131.7,129.7$, 129.1, 128.1, 125.9, 123.5, 119.4, $119.4\left(\mathrm{C}_{6} \mathrm{H}_{4}\right)$; 91.6, 87.7 (Cp); 52.7 $\left(\mathrm{C}_{\beta}\right) ; 50.8,44.1\left(\mathrm{NMe}_{2}\right) ; 20.1(\mathrm{O}=\mathrm{CMe})$.

$\left[\mathrm{Fe}_{2} \mathrm{Cp}_{2}(\mathrm{CO})(\mu-\mathrm{CO})\left\{\mu-\eta^{7}: \eta^{3}-\mathrm{C}_{\gamma}\left(3-\mathrm{C}_{6} \mathrm{H}_{4} \mathrm{OC}(=\mathrm{O})\left(\mathrm{CH}_{2}\right)_{3} \mathrm{C}_{6} \mathrm{H}_{4} \mathrm{~N}-\right.\right.\right.$ $\left.\left.\left.\left(\mathrm{CH}_{2} \mathrm{CH}_{2} \mathrm{Cl}\right)_{2}\right) \mathrm{C}_{\beta} \mathrm{HC}_{\alpha} \mathrm{NMe}_{2}\right\}\right] \mathrm{CF}_{3} \mathrm{SO}_{3}\left([8] \mathrm{CF}_{3} \mathrm{SO}_{3}\right)$ (Chart 7). This com-

\section{Chart 7. Structure of $[8]^{+}$}

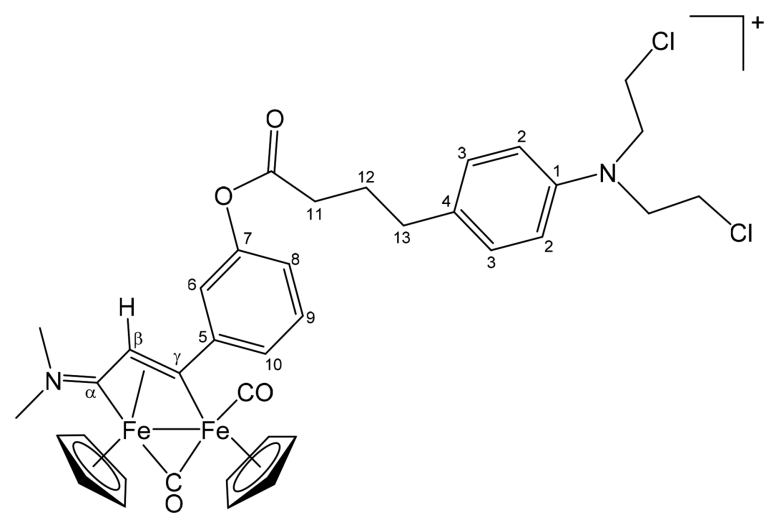

pound was obtained from $[\mathbf{1 a}] \mathrm{CF}_{3} \mathrm{SO}_{3}$ and $\mathrm{ALK}^{\mathrm{C}}$ : brown solid, yield 87\%. Anal. Calcd for $\mathrm{C}_{38} \mathrm{H}_{39} \mathrm{Cl}_{2} \mathrm{~F}_{3} \mathrm{Fe}_{2} \mathrm{~N}_{2} \mathrm{O}_{7} \mathrm{~S}$ : C, 50.30; $\mathrm{H}, 4.33 ; \mathrm{N}$, 3.09; S, 3.53. Found: C, 50.21; H, 4.26; N, 3.15; S, 3.58. IR $\left(\mathrm{CH}_{2} \mathrm{Cl}_{2}\right): \tilde{\nu} / \mathrm{cm}^{-1} 1992 \mathrm{vs}(\mathrm{CO}), 1809 \mathrm{~s}(\mu-\mathrm{CO}), 1758 \mathrm{~m}(\mathrm{OC}=\mathrm{O})$, $1690 \mathrm{w}\left(\mathrm{C}_{\beta} \mathrm{C}_{\alpha} \mathrm{N}\right), 1615 \mathrm{w}\left(\mathrm{C}-\mathrm{C}_{\text {arom }}\right), 1578 \mathrm{w}\left(\mathrm{C}-\mathrm{C}_{\text {arom }}\right), 1519 \mathrm{~s} .{ }^{1} \mathrm{H}$ NMR (acetone- $\left.d_{6}\right): \delta / \mathrm{ppm} 7.71\left(\mathrm{~d},{ }^{3} J_{\mathrm{H} 10-\mathrm{H} 9}=7.3 \mathrm{~Hz}, 1 \mathrm{H}, \mathrm{H}^{10}\right)$; $7.63\left(\right.$ br s, $\left.1 \mathrm{H}, \mathrm{H}^{6}\right) ; 7.59\left(\mathrm{t},{ }^{3} \mathrm{~J}=7.9 \mathrm{~Hz}, 1 \mathrm{H}, \mathrm{H}^{9}\right) ; 7.19\left(\mathrm{~d},{ }^{3} J_{\mathrm{H} 8-\mathrm{H} 9}=\right.$ $\left.7.9 \mathrm{~Hz}, 1 \mathrm{H}, \mathrm{H}^{8}\right) ; 7.15\left(\mathrm{~d},{ }^{3} \mathrm{~J}_{\mathrm{H} 3-\mathrm{H} 2}=8.6 \mathrm{~Hz}, 2 \mathrm{H}, \mathrm{H}^{3}\right) ; 6.78\left(\mathrm{~d},{ }^{3} J_{\mathrm{H} 2-\mathrm{H} 3}\right.$ $\left.=8.7 \mathrm{~Hz}, 2 \mathrm{H}, \mathrm{H}^{2}\right)$; 5.42, $5.29(\mathrm{~s}, 10 \mathrm{H}, \mathrm{Cp}) ; 4.72\left(\mathrm{~s}, 1 \mathrm{H}, \mathrm{C}_{\beta} \mathrm{H}\right) ; 4.06$, $3.48\left(\mathrm{~s}, 6 \mathrm{H}, \mathrm{NMe}_{2}\right) ; 3.81\left(\mathrm{~m}, 4 \mathrm{H}, \mathrm{NCH}_{2}\right) ; 3.75\left(\mathrm{~m}, 4 \mathrm{H}, \mathrm{CH}_{2} \mathrm{Cl}\right)$; $2.67\left(\mathrm{~m}, 4 \mathrm{H}, \mathrm{H}^{11}+\mathrm{H}^{13}\right) ; 2.08\left(\mathrm{~m}, 2 \mathrm{H}, \mathrm{H}^{12}\right) .{ }^{13} \mathrm{C}\left\{{ }^{1} \mathrm{H}\right\} \mathrm{NMR}$ $\left(\mathrm{CDCl}_{3}\right): \delta / \mathrm{ppm} 256.3\left(\mu\right.$-CO); $224.2\left(\mathrm{C}_{\alpha}\right) ; 209.5(\mathrm{CO}) ; 202.0$ $\left(\mathrm{C}_{\gamma}\right) ; 172.3(\mathrm{C}=\mathrm{O}) ; 156.7\left(\mathrm{C}^{5}\right) ; 150.5\left(\mathrm{C}^{7}\right) ; 144.5\left(\mathrm{C}^{1}\right) ; 130.2$ $\left(\mathrm{C}^{4}\right) ; 129.8\left(\mathrm{C}^{3}+\mathrm{C}^{10}\right) ; 123.9,120.8\left(\mathrm{C}^{6}+\mathrm{C}^{9}\right) ; 120.0\left(\mathrm{C}^{8}\right) ; 112.3$ $\left(\mathrm{C}^{2}\right)$; 91.0, $87.8(\mathrm{Cp})$; $53.6\left(\mathrm{NCH}_{2}\right)$; $53.2\left(\mathrm{C}_{\beta}\right)$; 52.0, $44.7\left(\mathrm{NMe}_{2}\right)$; $40.6\left(\mathrm{CH}_{2} \mathrm{Cl}\right) ; 34.0\left(\mathrm{C}^{13}\right)$; $33.9\left(\mathrm{C}^{11}\right) ; 26.7\left(\mathrm{C}^{12}\right)$.
$\left[\mathrm{Fe}_{2} \mathrm{Cp}_{2}(\mathrm{CO})(\mu-\mathrm{CO})\left\{\mu-\eta^{1}: \eta^{3}-\mathrm{C}_{\gamma}\left(3-\mathrm{C}_{6} \mathrm{H}_{4} \mathrm{NHC}(=\mathrm{O})\left(\mathrm{CH}_{2}\right)_{3} \mathrm{C}_{6} \mathrm{H}_{4} \mathrm{~N}-\right.\right.\right.$ $\left.\left.\left.\left(\mathrm{CH}_{2} \mathrm{CH}_{2} \mathrm{Cl}\right)_{2}\right) \mathrm{C}_{\beta} \mathrm{HC}_{\alpha} \mathrm{NMe}_{2}\right\}\right] \mathrm{CF}_{3} \mathrm{SO}_{3}\left([\mathrm{9}] \mathrm{CF}_{3} \mathrm{SO}_{3}\right)$ (Chart 8). This com-

Chart 8. Structure of $[9]^{+}$

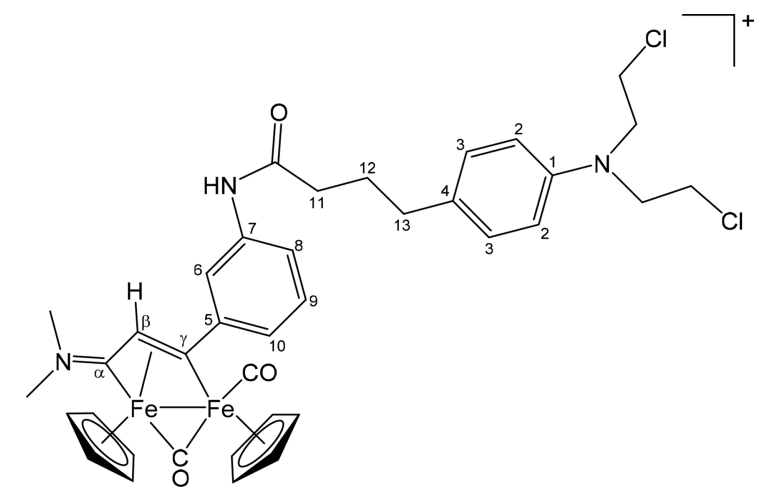

pound was obtained from $[\mathbf{1 a}] \mathrm{CF}_{3} \mathrm{SO}_{3}$ and $\mathrm{ALK}^{\mathrm{C} 2}$ : brown solid, yield 81\%. Anal. Calcd for $\mathrm{C}_{38} \mathrm{H}_{40} \mathrm{Cl}_{2} \mathrm{~F}_{3} \mathrm{Fe}_{2} \mathrm{~N}_{3} \mathrm{O}_{6} \mathrm{~S}$ : C, 50.35; H, 4.45; N, 4.64; S, 3.54. Found: $\mathrm{C}, 50.24 ; \mathrm{H}, 4.53 ; \mathrm{N}, 4.57 ; \mathrm{S}, 3.61$. IR $\left(\mathrm{CH}_{2} \mathrm{Cl}_{2}\right): \tilde{\nu} / \mathrm{cm}^{-1}$ 1991vs (CO), 1808s $\left(\mu\right.$-CO), 1683br-s $\left(\mathrm{C}_{\beta} \mathrm{C}_{\alpha} \mathrm{N}+\right.$ $\mathrm{NC}=O), 1615 \mathrm{~m}\left(\mathrm{C}-\mathrm{C}_{\text {arom }}\right), 1602 \mathrm{~m}, 1584 \mathrm{~m}\left(\mathrm{C}-\mathrm{C}_{\text {arom }}\right), 1519 \mathrm{vs} .{ }^{1} \mathrm{H}$ NMR (acetone- $\left.d_{6}\right): \delta /$ ppm $9.52(\mathrm{~s}, 1 \mathrm{H}, \mathrm{NH}) ; 8.53\left(\mathrm{~s}, 1 \mathrm{H}, \mathrm{H}^{6}\right) ; 7.52$ $\left(\mathrm{d},{ }^{3} \mathrm{~J}_{\mathrm{H} 8-\mathrm{H} 9}=7.9 \mathrm{~Hz}, 1 \mathrm{H}, \mathrm{H}^{8}\right) ; 7.45\left(\mathrm{t},{ }^{3} J=7.7 \mathrm{~Hz}, 1 \mathrm{H}, \mathrm{H}^{9}\right) ; 7.38(\mathrm{~d}$, $\left.{ }^{3} J_{\mathrm{H} 10-\mathrm{H} 9}=7.1 \mathrm{~Hz}, 1 \mathrm{H}, \mathrm{H}^{10}\right) ; 7.12\left(\mathrm{~d},{ }^{3} \mathrm{~J}_{\mathrm{H} 3-\mathrm{H} 2}=8.2 \mathrm{~Hz}, 2 \mathrm{H}, \mathrm{H}^{3}\right) ; 6.74$ $\left(\mathrm{d},{ }^{3} \mathrm{~J}_{\mathrm{H} 2-\mathrm{H} 3}=8.2 \mathrm{~Hz}, 2 \mathrm{H}, \mathrm{H}^{2}\right)$; 5.41, $5.26(\mathrm{~s}, 10 \mathrm{H}, \mathrm{Cp}) ; 4.68(\mathrm{~s}, 1 \mathrm{H}$, $\left.\mathrm{C}_{\beta} \mathrm{H}\right)$; 4.04, 3.45 (s, $\left.6 \mathrm{H}, \mathrm{NMe}_{2}\right)$; $3.78\left(\mathrm{~m}, 4 \mathrm{H}, \mathrm{NCH}_{2}\right)$; 3.74 (m, 4 $\left.\mathrm{H}, \mathrm{CH}_{2} \mathrm{Cl}\right) ; 2.61\left(\mathrm{t},{ }^{3} J_{\mathrm{H} 13-\mathrm{H} 12}=7.4 \mathrm{~Hz}, 2 \mathrm{H}, \mathrm{H}^{13}\right) ; 2.48\left(\mathrm{t},{ }^{3} J_{\mathrm{H} 11-\mathrm{H} 12}=\right.$ $\left.7.2 \mathrm{~Hz}, 2 \mathrm{H}, \mathrm{H}^{11}\right) ; 1.99\left(\mathrm{~m}, 2 \mathrm{H}, \mathrm{H}^{12}\right) .{ }^{13} \mathrm{C}\left\{{ }^{1} \mathrm{H}\right\}$ NMR (acetone- $d_{6}$ ): $\delta /$ ppm $255.9\left(\mu\right.$-CO); $225.1\left(\mathrm{C}_{\alpha}\right) ; 210.0(\mathrm{CO}) ; 204.1\left(\mathrm{C}_{\gamma}\right) ; 171.8$ $(\mathrm{C}=\mathrm{O}) ; 156.6\left(\mathrm{C}^{5}\right) ; 144.7\left(\mathrm{C}^{1}\right) ; 139.5\left(\mathrm{C}^{7}\right) ; 130.6\left(\mathrm{C}^{4}\right) ; 129.5$ $\left(\mathrm{C}^{3}\right)$; $128.6\left(\mathrm{C}^{9}\right)$; $121.6\left(\mathrm{C}^{10}\right)$; $118.5\left(\mathrm{C}^{6}\right)$; $117.4\left(\mathrm{C}^{8}\right)$; $112.3\left(\mathrm{C}^{2}\right)$; 91.7, $87.8(\mathrm{Cp}) ; 53.1\left(\mathrm{NCH}_{2}\right) ; 52.9\left(\mathrm{C}_{\beta}\right) ; 50.8,44.2\left(\mathrm{NMe}_{2}\right) ; 40.8$ $\left(\mathrm{CH}_{2} \mathrm{Cl}\right) ; 36.4\left(\mathrm{C}^{11}\right) ; 34.0\left(\mathrm{C}^{13}\right) ; 27.4\left(\mathrm{C}^{12}\right)$.

$\left[\mathrm{Fe}_{2} \mathrm{Cp}_{2}(\mathrm{CO})(\mu-\mathrm{CO})\left\{\mu-\eta^{7}: \eta^{3}-\mathrm{C}_{\gamma}\left(4-\mathrm{C}_{6} \mathrm{H}_{4} \mathrm{NHC}(=\mathrm{O})\left(\mathrm{CH}_{2}\right)_{3} \mathrm{C}_{6} \mathrm{H}_{4} \mathrm{~N}-\right.\right.\right.$ $\left.\left.\left.\left(\mathrm{CH}_{2} \mathrm{CH}_{2} \mathrm{Cl}\right)_{2}\right) \mathrm{C}_{\beta} \mathrm{HC}_{\alpha} \mathrm{NMe}_{2}\right\}\right] \mathrm{CF}_{3} \mathrm{SO}_{3} \quad\left([10] \mathrm{CF}_{3} \mathrm{SO}_{3}\right)$ (Chart 9). This

Chart 9. Structure of $[10]^{+}$

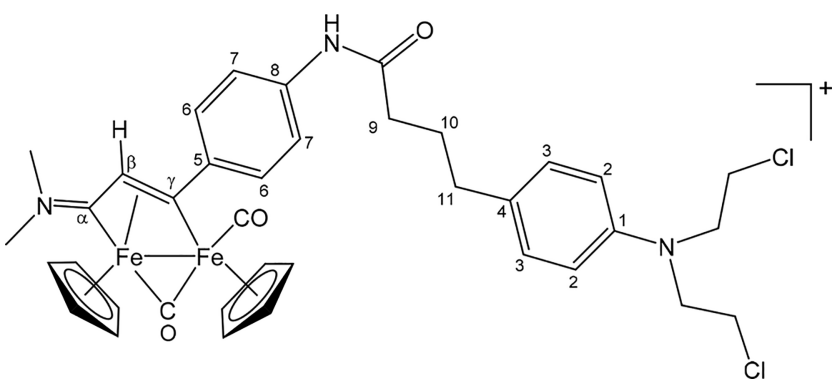

compound was obtained from $[\mathbf{1 a}] \mathrm{CF}_{3} \mathrm{SO}_{3}$ and $\mathrm{ALK}^{\mathrm{C} 3}$ : brown solid, yield 64\%. Anal. Calcd for $\mathrm{C}_{38} \mathrm{H}_{40} \mathrm{Cl}_{2} \mathrm{~F}_{3} \mathrm{Fe}_{2} \mathrm{~N}_{3} \mathrm{O}_{6} \mathrm{~S}$ : C, 50.35; $\mathrm{H}$, 4.45; N, 4.64; S, 3.54. Found: C, 50.23; H, 4.51; N, 4.69; S, 3.62. IR $\left(\mathrm{CH}_{2} \mathrm{Cl}_{2}\right): \tilde{\nu} / \mathrm{cm}^{-1}=1992 \mathrm{vs}(\mathrm{CO}), 1808 \mathrm{~s}(\mu$-CO $), 1691 \mathrm{br}-\mathrm{s}\left(\mathrm{C}_{\beta} \mathrm{C}_{\alpha} \mathrm{N}\right.$ $+\mathrm{NC}=\mathrm{O}), 1614 \mathrm{~m}\left(\mathrm{C}-\mathrm{C}_{\text {arom }}\right), 1606 \mathrm{~m}, 1586 \mathrm{~m}\left(\mathrm{C}-\mathrm{C}_{\text {arom }}\right), 1518 \mathrm{vs}$. ${ }^{1} \mathrm{H}$ NMR (acetone- $\left.d_{6}\right): \delta / \mathrm{ppm} 9.38(\mathrm{~s}, 1 \mathrm{H}, \mathrm{NH}) ; 7.87\left(\mathrm{~d},{ }^{3} J_{\mathrm{H} 7-\mathrm{H} 6}=\right.$ $\left.8.5 \mathrm{~Hz}, 2 \mathrm{H}, \mathrm{H}^{7}\right) ; 7.79\left(\mathrm{~d},{ }^{3} \mathrm{~J}_{\mathrm{H} 6-\mathrm{H} 7}=8.6 \mathrm{~Hz}, 2 \mathrm{H}, \mathrm{H}^{6}\right) ; 7.14\left(\mathrm{~d},{ }^{3} J_{\mathrm{H} 3-\mathrm{H} 2}\right.$ $\left.=8.6 \mathrm{~Hz}, 2 \mathrm{H}, \mathrm{H}^{3}\right) ; 6.78\left(\mathrm{~d},{ }^{3} J_{\mathrm{H} 2-\mathrm{H} 3}=8.6 \mathrm{~Hz}, 2 \mathrm{H}, \mathrm{H}^{2}\right) ; 5.40,5.29(\mathrm{~s}$, $10 \mathrm{H}, \mathrm{Cp}) ; 4.63\left(\mathrm{~s}, 1 \mathrm{H}, \mathrm{C}_{\beta} \mathrm{H}\right)$; 4.05, 3.47 (s, $\left.6 \mathrm{H}, \mathrm{NMe}_{2}\right) ; 3.80(\mathrm{~m}, 4$ $\left.\mathrm{H}, \mathrm{NCH}_{2}\right) ; 3.77\left(\mathrm{~m}, 4 \mathrm{H}, \mathrm{CH}_{2} \mathrm{Cl}\right) ; 2.64\left(\mathrm{t},{ }^{3} J_{\mathrm{H} 11-\mathrm{H} 10}=7.3 \mathrm{~Hz}, 2 \mathrm{H}\right.$, $\left.\mathrm{H}^{11}\right) ; 2.46\left(\mathrm{t},{ }^{3} \mathrm{~J}_{\mathrm{H} 9-\mathrm{H} 10}=7.5 \mathrm{~Hz}, 2 \mathrm{H}, \mathrm{H}^{9}\right) ; 2.02\left(\mathrm{~m}, 2 \mathrm{H}, \mathrm{H}^{10}\right)$. ${ }^{13} \mathrm{C}\left\{{ }^{1} \mathrm{H}\right\}$ NMR (acetone- $\left.d_{6}\right): \delta / \mathrm{ppm} 256.2\left(\mu\right.$-CO); $225.4\left(\mathrm{C}_{\alpha}\right)$; $210.1(\mathrm{CO}) ; 203.7\left(\mathrm{C}_{\gamma}\right) ; 171.4(\mathrm{C}=\mathrm{O}) ; 151.6\left(\mathrm{C}^{5}\right) ; 144.8\left(\mathrm{C}^{1}\right)$; $138.8\left(C^{8}\right) ; 130.7\left(C^{4}\right) ; 129.5\left(C^{3}\right) ; 128.0\left(C^{6}\right) ; 118.7\left(C^{7}\right) ; 112.3$ $\left(\mathrm{C}^{2}\right)$; 91.6, $87.7(\mathrm{Cp})$; $53.1\left(\mathrm{NCH}_{2}\right)$; $52.6\left(\mathrm{C}_{\beta}\right)$; 50.9, $44.2\left(\mathrm{NMe}_{2}\right)$; $40.8\left(\mathrm{CH}_{2} \mathrm{Cl}\right) ; 36.3\left(\mathrm{C}^{9}\right) ; 34.0\left(\mathrm{C}^{11}\right) ; 27.5\left(\mathrm{C}^{10}\right)$. 
Cell Culture and Cytotoxicity Studies. Human ovarian carcinoma (A2780 and A2780cisR) cell lines were obtained from the European Collection of Cell Cultures. The Human Embryonic Kidney 293T (HEK 293T) cell line was obtained from the ATCC (Sigma, Buchs, Switzerland). Penicillin-streptomycin, RPMI 1640 GlutaMAX (where RPMI = Roswell Park Memorial Institute), and DMEM GlutaMAX media (where DMEM = Dulbecco's modified Eagle medium) were obtained from Life Technologies, and fetal bovine serum (FBS) was obtained from Sigma. The cells were cultured in RPMI 1640 GlutaMAX (A2780 and A2780cisR) and DMEM GlutaMAX (HEK 293T) media containing 10\% heatinactivated FBS and $1 \%$ penicillin-streptomycin at $37{ }^{\circ} \mathrm{C}$ and $\mathrm{CO}_{2}$ (5\%). The A2780cisR cell line was routinely treated with cisplatin (2 $\mu \mathrm{M})$ in the media to maintain cisplatin resistance. The cytotoxicity was determined using the 3-(4,5-dimethyl-2-thiazolyl)-2,5-diphenyl$2 \mathrm{H}$-tetrazolium bromide (MTT) assay. ${ }^{42}$ Cells were seeded in flatbottomed 96-well plates as a suspension in a prepared medium (100 $\mu \mathrm{L}$ aliquots and approximately 4300 cells/well) and preincubated for $24 \mathrm{~h}$. Stock solutions of compounds were prepared in DMSO and were diluted in the medium. The solutions were sequentially diluted to give a final DMSO concentration of $0.5 \%$ and a final compound concentration range of $0-200 \mu \mathrm{M}$. Cisplatin was tested as a positive $(0-100 \mu \mathrm{M})$ control. The compounds were placed in the preincubated 96-well plates in $100 \mu \mathrm{L}$ aliquots, and the plates were incubated for a further $72 \mathrm{~h}$. MTT $(20 \mu \mathrm{L}, 5 \mathrm{mg} / \mathrm{mL}$ in Dulbecco's phosphate buffered saline) was placed in the cells, and the plates were incubated for a further $4 \mathrm{~h}$. The culture medium was aspirated, and the purple formazan crystals, formed by the mitochondrial dehydrogenase activity of vital cells, were dissolved in DMSO (100 $\mu \mathrm{L} /$ well). The absorbance of the resulting solutions, directly proportional to the number of surviving cells, was quantified at 590 $\mathrm{nm}$ using a SpectroMax M5e multimode microplate reader (using SoftMax Pro software, version 6.2.2). The percentage of surviving cells was calculated from the absorbance of wells corresponding to the untreated control cells. The reported $\mathrm{IC}_{50}$ values are based on the means from two independent experiments, each comprising four tests per concentration level.

ROS Determination. The intracellular production of reactive oxygen species (ROS) upon treatment of the complexes $[4] \mathrm{CF}_{3} \mathrm{SO}_{3}$ and $[9] \mathrm{CF}_{3} \mathrm{SO}_{3}$ was measured by using the DCFH-DA $\left(2^{\prime}, 7^{\prime}-\right.$ dichlorodihydrofluorescein diacetate, Sigma-Aldrich) assay, based on the cellular uptake of the nonfluorescent diacetate following deacetylation by esterases $\left(2^{\prime}, 7^{\prime}\right.$-dichlorodihydrofluorescein, DCFH) and oxidation to the fluorescent dichlorofluorescein $\left(2^{\prime}, 7^{\prime}\right.$-dichlorofluorescein, DCF) ${ }^{43}$ A2780 cells were seeded at a concentration of 4 $\times 10^{4}$ cells per well in $90 \mu \mathrm{L}$ of complete growth medium into 96-well plates. After overnight incubation, the cells were treated following the manufacturer's protocol. A $100 \mu \mathrm{L}$ portion of a solution containing the fluorogenic probe was added to the culture medium and, after $1 \mathrm{~h}$ of incubation with $5 \% \mathrm{CO}_{2}$ at $37{ }^{\circ} \mathrm{C}$, cells were exposed with a final concentration of $10 \mu \mathrm{M}$ of the tested compound; $\mathrm{H}_{2} \mathrm{O}_{2} 100 \mu \mathrm{M}$ was used as a positive control. Stock solutions of compounds were prepared as described above; cells incubated with equal amounts of DMSO in supplemented RPMI were used as a control. The fluorescence was measured up to $24 \mathrm{~h}$ with an excitation wavelength of $485 \mathrm{~nm}$ and with a $535 \mathrm{~nm}$ emission filter by Multilabel Counter (PerkinElmer, Waltham, MA, USA). The measurements were performed in triplicate, and results were reported as mean $\pm S D$. Statistical differences were examined using one-way analysis of variance (ANOVA), and a Tukey test was used for post hoc analysis. A $p$ value $<0.05$ was considered statistically significant.

COX-2 Inhibition Assays. The enzymatic activity of COX-2 $(0.25 \mathrm{UN})$ was fluorimetrically assayed at $576 \mathrm{~nm} / 586 \mathrm{~nm}$ at $25^{\circ} \mathrm{C}$ by measuring the conversion rate of arachidonic acid (ARA) into resorufin by COX-2 as a function of time (COX-2 assay kit from Cayman Chemical Company, Ann Arbor, MI, USA). The assay mixture contained $25 \mu \mathrm{M}$ ADHP, $5 \mu \mathrm{M}$ hemin, and $37.5 \mu \mathrm{M}$ ARA in $0.1 \mathrm{M}$ Tris- $\mathrm{HCl}$ buffer ( $\mathrm{pH} 8)$. The inhibitory efficacy of the tested compounds was determined by recording the residual activity of COX-2 in the presence of variable concentrations of the analyzed compound $(11-705 \mu \mathrm{M})$. The $\mathrm{IC}_{50}$ value was obtained using GraphPad Prism 7 software. All of the inhibitor assays were performed at least in triplicate.

Interaction with Biomolecules. Ethidium bromide (EB, $\geq 98.0 \%$ ), bovine serum albumin (BSA, lyophilized powder, crystallized, $\geq 98.0 \%$ ), and natural double-stranded DNA from calf thymus (DNA, lyophilized powder, $\mathrm{Na}^{+}$salt in the form of fibers) were purchased from Merck, while anhydrous guanosine 5'-monophosphate disodium salt $\left(\mathrm{Na}_{2}[\mathrm{GMP}],>98.0 \%\right)$ was purchased from TCI Chemicals. Prior to use, DNA was sonicated to ca. 500 base pair length (MSE-Sonyprep sonicator, 7 cycles of $10 \mathrm{~s}$ sonication $+20 \mathrm{~s}$ pause at an amplitude of $14 \mu \mathrm{m}$, solution kept in ice bath-the final length was checked by agarose gel electrophoresis tests on the sample using a $100 \mathrm{bp}$ DNA ladder) to produce stock solutions in water (ca. $2 \mathrm{mM}$ ). Stock solutions of EB and BSA were prepared by weighing directly in the buffer $(\mathrm{NaCl} 0.1 \mathrm{M}, \mathrm{NaCac} 0.01 \mathrm{M}, \mathrm{pH} 7.0-\mathrm{NaCac}$ is sodium cacodylate). A temperature-controlled $\left( \pm 0.1{ }^{\circ} \mathrm{C}\right)$ Shimadzu UV2450 spectrophotometer and PerkinElmer LS55 spectrofluorometer were the instruments used. Molar concentrations of solutions of EB $\left(C_{\mathrm{EB}}\right)$, BSA $\left(C_{\mathrm{BSA}}\right)$, and DNA $\left(C_{\mathrm{DNA}}\right)$ were determined by absorbance measurements $\left(\varepsilon_{\mathrm{EB}}^{480 \mathrm{~nm}}=5700 \mathrm{M}^{-1} \mathrm{~cm}^{-1} ; \varepsilon_{\mathrm{BSA}}{ }^{278 \mathrm{~nm}}=\right.$ $44000 \mathrm{M}^{-1} \mathrm{~cm}^{-1} ; \varepsilon_{\mathrm{DNA}}{ }^{260 \mathrm{~nm}}=13200 \mathrm{M}^{-1} \mathrm{~cm}^{-1}$ for a concentration expressed in base pairs). Solutions of the metal complex were prepared by weighing an appropriate amount of the solid and dissolving it in DMSO (ca. $5 \mathrm{mM}$ ). Ultrapure water (Sartorius) was the reaction medium. In EB/DNA exchange experiments, EB was added to DNA until the fluorescence emission at $\lambda_{\mathrm{ex}}=520 \mathrm{~nm} / \lambda_{\mathrm{em}}=$ $595 \mathrm{~nm}$ (diagnostic wavelengths for the DNA-intercalated EB only) started to reach the plateau $\left(C_{\mathrm{EB}}=5.60 \times 10^{-5} \mathrm{M}, C_{\mathrm{DNA}}=1.15 \times\right.$ $\left.10^{-4} \mathrm{M}\right)$. The concentrated stock solution of the metal complex was then directly added in small amounts to the EB/DNA mixture with a gastight syringe connected to a Mitutoyo micrometric screw ( 1 total turn of the screw $=8.2 \mu \mathrm{L}$ ). The total maximum amount of DMSO was checked $(<3 \%)$ as well as the metal complex absorbance at the set wavelengths $(A<0.05$ to ensure negligible inner filter effects). Note that a blank test was carried out by adding DMSO to the EB/DNA mixture, in order to quantify fluorescence changes due only to dilution/solvent effects. For BSA fluorescence titrations, the working solution of the metal complex $\left(4.42 \times 10^{-5} \mathrm{M}\right.$ for $[4] \mathrm{CF}_{3} \mathrm{SO}_{3}, 4.59 \times$ $10^{-5} \mathrm{M}$ for [9] $\mathrm{CF}_{3} \mathrm{SO}_{3}$, both in the buffer) was added to a $3.34 \times$ $10^{-7} \mathrm{M}$ BSA solution in the buffer $\left(\lambda_{\mathrm{ex}}=280 \mathrm{~nm}, \lambda_{\mathrm{em}}=345 \mathrm{~nm}\right.$, dilution from stock such that the DMSO content is negligible). Each experiment was performed at least in duplicate; the reported values are mean values over the replicates (error $<5 \%$ ).

In order to analyze the interaction with a model nucleotide, a freshly prepared solution of $[9] \mathrm{CF}_{3} \mathrm{SO}_{3}(2 \mathrm{mg})$ in $\mathrm{D}_{2} \mathrm{O} / \mathrm{CD}_{3} \mathrm{OD}(5 / 3$ $\mathrm{v} / \mathrm{v}$ ) was treated with 1 equiv of anhydrous $\mathrm{Na}_{2}[\mathrm{GMP}]$. The resulting mixture was maintained at $37^{\circ} \mathrm{C}$ for $24 \mathrm{~h}$, and then the final solution was filtered in order to remove some solid and analyzed by mass spectrometry. HPLC-MS(+): $m / z$ found 1087.2451 $\left[9^{\mathrm{GMP}}+\mathrm{Na}\right]^{+}$, calcd for $\mathrm{C}_{47} \mathrm{H}_{53} \mathrm{Fe}_{2} \mathrm{~N}_{8} \mathrm{NaO}_{12} \mathrm{P}$ 1087.2117; $\mathrm{m} / z$ found 555.0666 $\left[9^{\mathrm{GMP}}+2 \mathrm{Na}\right]^{2+}$, calcd for $\mathrm{C}_{47} \mathrm{H}_{53} \mathrm{Fe}_{2} \mathrm{~N}_{8} \mathrm{Na}_{2} \mathrm{O}_{12} \mathrm{P}$ 555.1008. The isotopic patterns fit well the calculated patterns.

\section{ASSOCIATED CONTENT}

\section{(3) Supporting Information}

The Supporting Information is available free of charge at https://pubs.acs.org/doi/10.1021/acs.organomet.1c00270.

Synthesis and characterization of alkynes, X-ray crystallography, solubility and stability in aqueous media, determination of partition coefficients, BSA binding studies, and NMR spectra of products (PDF)

\section{Accession Codes}

CCDC 2076710-2076712 contain the supplementary crystallographic data for this paper. These data can be obtained free of charge via www.ccdc.cam.ac.uk/data_request/cif, or by emailing data_request@ccdc.cam.ac.uk, or by contacting The 
Cambridge Crystallographic Data Centre, 12 Union Road, Cambridge CB2 1EZ, UK; fax: +44 1223336033.

\section{AUTHOR INFORMATION}

\section{Corresponding Author}

Fabio Marchetti - University of Pisa, Dipartimento di Chimica e Chimica Industriale, 56124 Pisa, Italy; () orcid.org/0000-0002-3683-8708;

Email: fabio.marchetti1974@unipi.it; http:// people.unipi.it/fabio_marchetti1974/

\section{Authors}

Silvia Schoch - University of Pisa, Dipartimento di Chimica e Chimica Industriale, 56124 Pisa, Italy

Mouna Hadiji - Institut des Sciences et Ingénierie Chimiques, Ecole Polytechnique Fédérale de Lausanne (EPFL), Lausanne, Switzerland

Sarah A. P. Pereira - LAQV, REQUIMTE, Laboratório de Química Aplicada, Faculdade de Farmácia, Universidade do Porto, Porto, Portugal

M. Lúcia M. F. S. Saraiva - LAQV, REQUIMTE, Laboratório de Química Aplicada, Faculdade de Farmácia, Universidade do Porto, Porto, Portugal; (1) orcid.org/00000001-6539-1741

Simona Braccini - University of Pisa, Dipartimento di Chimica e Chimica Industriale, 56124 Pisa, Italy

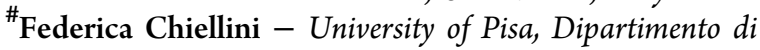
Chimica e Chimica Industriale, 56124 Pisa, Italy; (1) orcid.org/0000-0003-4680-9975

Tarita Biver - University of Pisa, Dipartimento di Farmacia, 56126 Pisa, Italy; University of Pisa, Dipartimento di Chimica e Chimica Industriale, 56124 Pisa, Italy; () orcid.org/0000-0001-8512-8422

Stefano Zacchini - University of Bologna, Dipartimento di Chimica Industriale "Toso Montanari", 40136 Bologna, Italy; (1) orcid.org/0000-0003-0739-0518

Guido Pampaloni - University of Pisa, Dipartimento di Chimica e Chimica Industriale, 56124 Pisa, Italy; (1) orcid.org/0000-0002-6375-4411

Paul J. Dyson - Institut des Sciences et Ingénierie Chimiques, Ecole Polytechnique Fédérale de Lausanne (EPFL),

Lausanne, Switzerland; 이이.org/0000-0003-3117-3249

Complete contact information is available at:

https://pubs.acs.org/10.1021/acs.organomet.1c00270

\section{Notes}

The authors declare no competing financial interest.

\#Deceased in March 2021.

\section{ACKNOWLEDGMENTS}

We gratefully thank the University of Pisa (PRA_2020_39: "New horizons in $\mathrm{CO}_{2}$ chemistry: from capture to fine chemicals and metal based drugs") for financial support, Prof. Ilaria Degano (University of Pisa) for the execution of mass spectrometry analyses and helpful discussions, and the CIRCMSB (Consorzio Inter-Universitario di Ricerca in Chimica dei Metalli nei Sistemi Biologici). This contribution is part of the work from COST Action CA18202, NECTARNetwork for Equilibria and Chemical Thermodynamics Advanced Research, supported by COST (European Cooperation in Science and Technology).

\section{REFERENCES}

(1) (a) Oun, R.; Moussa, Y. E.; Wheate, N. J. The side effects of platinum-based chemotherapy drugs: a review for chemists. Dalton Trans. 2018, 47, 6645-6653. (b) Siddik, Z. H. Cisplatin Mode of Cytotoxic Action and Molecular Basis of Resistance. Oncogene 2003, 22, 7265-7279. (c) Apps, M. G.; Choi, E. H. Y.; Wheate, N. J. The state-of-play and future of platinum drugs. Endocr-Relat. Cancer 2015, 22, R219-R233.

(2) Selected recent reviews: (a) Murray, B. S.; Dyson, P. J. Recent progress in the development of organometallics for the treatment of cancer. Curr. Opin. Chem. Biol. 2020, 56, 28-34. (b) Zhang, P.; Sadler, P. J. Advances in the design of organometallic anticancer complexes. J. Organomet. Chem. 2017, 839, 5-14. (c) Lazarevič, T.; Rilak, A.; Bugarčič, Z. D. Platinum, palladium, gold and ruthenium complexes as anticancer agents: Current clinical uses, cytotoxicity studies and future perspectives. Eur. J. Med. Chem. 2017, 142, 8-31. (d) Meier-Menches, S. M.; Gerner, C.; Berger, W.; Hartinger, C. G.; Keppler, B. K. Structure-activity relationships for ruthenium and osmium anticancer agents - towards clinical development. Chem. Soc. Rev. 2018, 47, 909-928. (e) Mora, M.; Gimeno, M. C.; Visbal, R. Recent advances in gold-NHC complexes with biological properties. Chem. Soc. Rev. 2019, 48, 447-462.

(3) Kaim, W.; Schwederski, B.; Klein, A. iIn Bioinorganic Chemistry: Inorganic Elements in the Chemistry of Life, 2nd ed.; Wiley: 2013.

(4) (a) Jaouen, G.; Vessieres, A.; Top, S. Ferrocifen type anti cancer drugs. Chem. Soc. Rev. 2015, 44, 8802-8817. (b) Patra, M.; Gasser, G. The medicinal chemistry of ferrocene and its derivatives. Nat. Chem. Rev. 2017, 1, 0066.

(5) (a) Wang, Y.; Dansette, P. M.; Pigeon, P.; Top, S.; McGlinchey, M. J.; Mansuy, D.; Jaouen, G. A new generation of ferrociphenols leads to a great diversity of reactive metabolites, and exhibits remarkable antiproliferative properties. Chem. Sci. 2018, 9, 70-78. (b) Leonidova, A.; Anstaett, P.; Pierroz, V.; Mari, C.; Spingler, B.; Ferrari, S.; Gasser, G. Induction of Cytotoxicity through Photorelease of Aminoferrocene. Inorg. Chem. 2015, 54, 9740-9748. (c) Ocasio, C. A.; Sansook, S.; Jones, R.; Roberts, J. M.; Scott, T. G.; Tsoureas, N.; Coxhead, P.; Guille, M.; Tizzard, G. J.; Coles, S. J.; Hochegger, H.; Bradner, J. E.; Spencer, J. Pojamide: An HDAC3-Selective Ferrocene Analogue with Remarkably Enhanced Redox-Triggered Ferrocenium Activity in Cells. Organometallics 2017, 36, 3276-3283.

(6) (a) Pilon, A.; Gírio, P.; Nogueira, G.; Avecilla, F.; Adams, H.; Lorenzo, J.; Garcia, M. H.; Valente, A. New iron cyclopentadienyl complexes bearing different phosphane co-ligands: Structural factors vs. cytotoxicity. J. Organomet. Chem. 2017, 852, 34-42. (b) Florindo, P. R.; Pereira, D. M.; Borralho, P. M.; Rodrigues, C. M. P.; Piedade, M. F. M.; Fernandes, A. C. Cyclopentadienyl-Ruthenium(II) and Iron(II) Organometallic Compounds with Carbohydrate Derivative Ligands as Good Colorectal Anticancer Agents. J. Med. Chem. 2015, 58, 4339-4347. (c) Herry, B.; Batchelor, L. K.; Roufosse, B.; Romano, D.; Baumgartner, J.; Borzova, M.; Reifenstahl, T.; Collins, T.; Benamrane, A.; Weggelaar, J.; Correia, M. C.; Dyson, P. J.; Blom, B. Heterobimetallic $\mathrm{Ru}(\mu$-dppm $) \mathrm{Fe}$ and homobimetallic $\mathrm{Ru}(\mu$-dppm $)$ $\mathrm{Ru}$ complexes as potential anti-cancer agents. J. Organomet. Chem. 2019, 901, 120934.

(7) Agonigi, G.; Biancalana, L.; Lupo, M. G.; Montopoli, M.; Ferri, N.; Zacchini, S.; Binacchi, F.; Biver, T.; Campanella, B.; Pampaloni, G.; Zanotti, V.; Marchetti, F. Exploring the Anticancer Potential of Diiron Bis-cyclopentadienyl Complexes with Bridging Hydrocarbyl Ligands: Behavior in Aqueous Media and In Vitro Cytotoxicity. Organometallics 2020, 39, 645-657.

(8) See for instance: (a) Ritleng, V.; Chetcuti, M. J. Hydrocarbyl Ligand Transformations on Heterobimetallic Complexes. Chem. Rev. 2007, 107, 797-858. (b) Adams, R. D.; Captain, B. Bimetallic cluster complexes: Synthesis, structures and applications to catalysis. J. Organomet. Chem. 2004, 689, 4521-4529. (c) Patra, S.; Maity, N. Recent advances in (hetero)dimetallic systems towards tandem catalysis. Coord. Chem. Rev. 2021, 434, 213803. (d) van Niekerk, A.; Chellan, P.; Mapolie, S. F. Heterometallic Multinuclear Complexes 
as Anti-Cancer Agents- An Overview of Recent Developments. Eur. J. Inorg. Chem. 2019, 2019, 3432-3455.

(9) Selected reviews: (a) Mazzoni, R.; Salmi, M.; Zanotti, V. C-C Bond Formation in Diiron Complexes. Chem. - Eur. J. 2012, 18, 10174-10194. (b) Marchetti, F. Constructing Organometallic Architectures from Aminoalkylidyne Diiron Complexes. Eur. J. Inorg. Chem. 2018, 2018, 3987-4003. (c) García, M. E.; GarcíaVivó, D.; Ramos, A.; Ruiz, M. A. Phosphinidene-bridged binuclear complexes. Coord. Chem. Rev. 2017, 330, 1-36.

(10) (a) Ciancaleoni, G.; Zacchini, S.; Zanotti, V.; Marchetti, F. DFT Mechanistic Insights into the Alkyne Insertion Reaction Affording Diiron $\mu$-Vinyliminium Complexes and New Functionalization Pathways. Organometallics 2018, 37, 3718-3731. (b) Albano, V. G.; Busetto, L.; Marchetti, F.; Monari, M.; Zacchini, S.; Zanotti, V. Diiron $\mu$-Vinyliminium Complexes from Acetylene Insertion into a Metal-Aminocarbyne Bond. Organometallics 2003, 22, 1326-1331.

(11) Rocco, D.; Batchelor, L. K.; Agonigi, G.; Braccini, S.; Chiellini, F.; Schoch, S.; Biver, T.; Funaioli, T.; Zacchini, S.; Biancalana, L.; Ruggeri, M.; Pampaloni, G.; Dyson, P. J.; Marchetti, F. Anticancer Potential of Diiron Vinyliminium Complexes. Chem. - Eur. J. 2019, 25, 14801-14816.

(12) Rocco, D.; Busto, N.; Pérez-Arnaiz, C.; Biancalana, L.; Zacchini, S.; Pampaloni, G.; Garcia, B.; Marchetti, F. Antiproliferative and bactericidal activity of diiron and monoiron cyclopentadienyl carbonyl complexes comprising a vinyl-aminoalkylidene unit. Appl. Organomet. Chem. 2020, 34, No. e5923.

(13) Agonigi, G.; Batchelor, L. K.; Ferretti, E.; Schoch, S.; Bortoluzzi, M.; Braccini, S.; Chiellini, F.; Biancalana, L.; Zacchini, S.; Pampaloni, G.; Sarkar, B.; Dyson, P. J.; Marchetti, F. Mono-, Diand Tetra-iron Complexes with Selenium or Sulphur Functionalized Vinyliminium Ligands: Synthesis, Structural Characterization and Antiproliferative Activity. Molecules 2020, 25, 1656.

(14) Schoch, S.; Batchelor, L. K.; Funaioli, T.; Ciancaleoni, G.; Zacchini, S.; Braccini, S.; Chiellini, F.; Biver, T.; Pampaloni, G.; Dyson, P. J.; Marchetti, F. Diiron Complexes with a Bridging Functionalized Allylidene Ligand: Synthesis, Structural Aspects, and Cytotoxicity. Organometallics 2020, 39, 361-373.

(15) (a) Starha, P.; Trávníček, Z. Non-platinum complexes containing releasable biologically active ligands. Coord. Chem. Rev. 2019, 395, 130-145. (b) Kilpin, K. J.; Dyson, P. J. Enzyme inhibition by metal complexes: concepts, strategies and applications. Chem. Sci. 2013, 4, 1410-1419.

(16) (a) Hanif, M.; Hartinger, C. G. From the hypothesis-driven development of organometallic anticancer drugs to new methods in mode of action studies. Adv. Inorg. Chem. 2020, 75, 339-359. (b) Steel, T. R.; Walsh, F.; Wieczorek-Błauz, A.; Hanif, M.; Hartinger, C. G. Monodentately-coordinated bioactive moieties in multimodal half-sandwich organoruthenium anticancer agents. Coord. Chem. Rev. 2021, 439, 213890. (c) Gibson, D. Platinum(IV) anticancer agents; are we en route to the holy grail or to a dead end? J. Inorg. Biochem. 2021, 217, 111353.

(17) (a) Studer, V.; Anghel, N.; Desiatkina, O.; Felder, T.; Boubaker, G.; Amdouni, Y.; Ramseier, J.; Hungerbühler, M.; Kempf, C.; Heverhagen, J. T.; Hemphill, A.; Ruprecht, N.; Furrer, J.; Păunescu, E. Conjugates Containing Two and Three TrithiolatoBridged Dinuclear Ruthenium(II)-Arene Units as In Vitro Antiparasitic and Anticancer Agents. Pharmaceuticals 2020, 13, 471. (b) Reithofer, M. R.; Valiahdi, S. M.; Jakupec, M. A.; Arion, V. B.; Egger, A.; Galanski, M.; Keppler, B. K. Novel Di- and Tetracarboxylatoplatinum(IV) Complexes. Synthesis, Characterization, Cytotoxic Activity, and DNA Platination. J. Med. Chem. 2007, 50, 6692-6699. (c) Cabrera, S.; Navas, F.; Matesanz, A. I.; Maroto, M.; Riedel, T.; Dyson, P. J.; Quiroga, A. G. Versatile Route to transPlatinum(II) Complexes via Manipulation of a Coordinated 3(Pyridin-3-yl)propanoic Acid Ligand. Inorg. Chem. 2019, 58, 72007208.

(18) Chellan, P.; Sadler, P. J. Enhancing the Activity of Drugs by Conjugation to Organometallic Fragments. Chem. - Eur. J. 2020, 26, 8676-8688.
(19) (a) Singh, A.; Lumb, I.; Mehra, V.; Kumar, V. Ferroceneappended pharmacophores: an exciting approach for modulating the biological potential of organic scaffolds. Dalton Trans. 2019, 48, 2840-2860. (b) Sansook, S.; Hassell-Hart, S.; Ocasio, C.; Spencer, J. Ferrocenes in medicinal chemistry; a personal perspective. J. Organomet. Chem. 2020, 905, 121017. (c) Wang, R.; Chen, H.; Yan, W.; Zheng, M.; Zhang, T.; Zhang, Y. Ferrocene-containing hybrids as potential anticancer agents: Current developments, mechanisms of action and structure-activity relationships. Eur. J. Med. Chem. 2020, 190, 112109. (d) Błauz, A.; Rychlik, B.; Makal, A.; Szulc, K.; Strzelczyk, P.; Bujacz, G.; Zakrzewski, J.; Woẑniak, K.; Plaẑuk, D. Ferrocene-Biotin Conjugates: Synthesis, Structure, Cytotoxic Activity and Interaction with Avidin. ChemPlusChem 2016, 81, 1191-1201. (e) Gimeno, M. C.; Goitia, H.; Laguna, A.; Luque, M. E.; Villacampa, M. D.; Sepúlveda, C.; Meireles, M. Conjugates of ferrocene with biological compounds. Coordination to gold complexes and antitumoral properties. J. Inorg. Biochem. 2011, 105, 1373-1382.

(20) Prinz, C.; Vasyutina, E.; Lohmann, G.; Schrader, A.; Romanski, S.; Hirschhäuser, C.; Mayer, P.; Frias, C.; Herling, C. D.; Hallek, M.; Schmalz, H.-G.; Prokop, A.; Mougiakakos, D.; Herling, M. Organometallic nucleosides induce non-classical leukemic cell death that is mitochondrial-ROS dependent and facilitated by TCL1-oncogene burden. Mol. Cancer 2015, 14, 114.

(21) Aspirin: Cheng, Q.; Shi, H.; Wang, H.; Min, Y.; Wang, J.; Liu, $\mathrm{Y}$. The ligation of aspirin to cisplatin demonstrates significant synergistic effects on tumor cells. Chem. Commun. 2014, 50, 74277430.

(22) Chlorambucil: (a) Qin, X.; Fang, L.; Chen, F.; Gou, S. Conjugation of platinum(IV) complexes with chlorambucil to overcome cisplatin resistance via a "joint action" mode toward DNA. Eur. J. Med. Chem. 2017, 137, 167-175. (b) Nazarov, A. A.; Meier, S. M.; Zava, O.; Nosova, Y. N.; Milaeva, E. R.; Hartinger, C. G.; Dyson, P. J. Protein ruthenation and DNA alkylation: chlorambucil-functionalized RAPTA complexes and their anticancer activity. Dalton Trans. 2015, 44, 3614-3623.

(23) Fiala, C.; Pasic, M. D. Aspirin: Bitter pill or miracle drug? Clin. Biochem. 2020, 85, 1-4.

(24) Goede, V.; Eichhorst, B.; Fischer, K.; Wendtner, C.-M.; Hallek, M. Past, present and future role of chlorambucil in the treatment of chronic lymphocytic leukemia. Leuk. Lymphoma 2015, 56, 15851592.

(25) Rubner, G.; Bensdorf, K.; Wellner, A.; Kircher, B.; Bergemann, S.; Ott, I.; Gust, R. Synthesis and Biological Activities of Transition Metal Complexes Based on Acetylsalicylic Acid as Neo-Anticancer Agents. J. Med. Chem. 2010, 53, 6889-6898.

(26) Biancalana, L.; Batchelor, L. K.; Funaioli, T.; Zacchini, S.; Bortoluzzi, M.; Pampaloni, G.; Dyson, P. J.; Marchetti, F. $\alpha$-Diimines as Versatile, Derivatizable Ligands in Ruthenium(II) p-Cymene Anticancer Complexes. Inorg. Chem. 2018, 57, 6669-6685.

(27) Liu, J.; Huang, W.; Pang, Y.; Zhu, X.; Zhou, Y.; Yan, D. Hyperbranched Polyphosphates for Drug Delivery Application: Design, Synthesis, and In Vitro Evaluation. Biomacromolecules 2010, $11,1564-1570$.

(28) Agonigi, G.; Bortoluzzi, M.; Marchetti, F.; Pampaloni, G.; Zacchini, S.; Zanotti, V. Regioselective Nucleophilic Additions to Diiron Carbonyl Complexes Containing a Bridging Aminocarbyne Ligand: A Synthetic, Crystallographic and DFT Study. Eur. J. Inorg. Chem. 2018, 2018, 960-971.

(29) Albano, V. G.; Busetto, L.; Marchetti, F.; Monari, M.; Zacchini, S.; Zanotti, V. Stereochemistry of the insertion of disubstituted alkynes into the metal aminocarbyne bond in diiron complexes. J. Organomet. Chem. 2004, 689, 528-538.

(30) Biancalana, L.; Batchelor, L. K.; De Palo, A.; Zacchini, S.; Pampaloni, G.; Dyson, P. J.; Marchetti, F. A general strategy to add diversity to ruthenium arene complexes with bioactive organic compounds via a coordinated (4-hydroxyphenyl) diphenylphosphine ligand. Dalton Trans. 2017, 46, 12001-12004. 
(31) The previously reported value was aspirin $1160 \mathrm{mM}$ : Makkar, F.; Chakraborty, K. First report of dual cyclooxygenase-2 and 5lipoxygenase inhibitory halogen derivatives from the thallus of intertidal seaweed Kappaphycus alvarezii. Med. Chem. Res. 2018, 27, 2331-2340.

(32) Macii, F.; Biver, T. Spectrofluorimetric analysis of the binding of a target molecule to serum albumin: tricky aspects and tips. J. Inorg. Biochem. 2021, 216, 111305.

(33) HypSpec2014 software; http://www.hyperquad.co.uk/.

(34) (a) Tǒpala, T.; Pascual-Allvarez, A.; Moldes-Tolosa, M. Á.; Bodoki, A.; Castiñeiras, A.; Torres, J.; del Pozo, C.; Borrás, J.; AlzuetPiña, G. New sulfonamide complexes with essential metal ions [Cu(II), $\mathrm{Co}(\mathrm{II}), \mathrm{Ni}(\mathrm{II})$ and $\mathrm{Zn}(\mathrm{II})]$. Effect of the geometry and the metal ion on DNA binding and nuclease activity. BSA protein interaction. J. Inorg. Biochem. 2020, 202, 110823. (b) Elsadek, B.; Kratz, F. Impact of albumin on drug delivery-New applications on the horizon. J. Controlled Release 2012, 157, 4-28.

(35) Schmidt, K.; Jung, M.; Keilitz, R.; Schnurr, B.; Gust, R. Acetylenehexacarbonyldicobalt complexes, a novel class of antitumor drugs. Inorg. Chim. Acta 2000, 306, 6-16.

(36) Provinciali, G.; Bortoluzzi, M.; Funaioli, T.; Zacchini, S.; Campanella, B.; Pampaloni, G.; Marchetti, F. Tetrasubstituted Selenophenes from the Stepwise Assembly of Molecular Fragments on a Diiron Frame and Final Cleavage of a Bridging Alkylidene. Inorg. Chem. 2020, 59, 17497-17508.

(37) Agonigi, G.; Ciancaleoni, G.; Funaioli, T.; Zacchini, S.; Pineider, F.; Pinzino, C.; Pampaloni, G.; Zanotti, V.; Marchetti, F. Controlled Dissociation of Iron and Cyclopentadienyl from a Diiron Complex with a Bridging $\mathrm{C}_{3}$ Ligand Triggered by One-Electron Reduction. Inorg. Chem. 2018, 57, 15172-15186.

(38) Menges, F. Spectragryph - optical spectroscopy software, Ver. 1.2.5, 2016-2017; http://www.effemm2.de/spectragryph.

(39) Fulmer, G. R.; Miller, A. J. M.; Sherden, N. H.; Gottlieb, H. E.; Nudelman, A.; Stoltz, B. M.; Bercaw, J. E.; Goldberg, K. I. NMR Chemical Shifts of Trace Impurities: Common Laboratory Solvents, Organics, and Gases in Deuterated Solvents Relevant to the Organometallic Chemist. Organometallics 2010, 29, 2176-2179.

(40) Willker, W.; Leibfritz, D.; Kerssebaum, R.; Bermel, W. Gradient selection in inverse heteronuclear correlation spectroscopy. Magn. Reson. Chem. 1993, 31, 287-292.

(41) Albano, V. G.; Busetto, L.; Monari, M.; Zanotti, V. Reactions of acetonitrile di-iron $\mu$-aminocarbyne complexes; synthesis and structure of $\left[\mathrm{Fe}_{2}\left(\mu-\mathrm{CNMe}_{2}\right)(\mu-\mathrm{H})(\mathrm{CO})_{2}(\mathrm{Cp})_{2}\right]$. J. Organomet. Chem. 2000, 606, 163-168.

(42) Mosmann, T. Rapid colorimetric assay for cellular growth and survival: application to proliferation and cytotoxicity assays. J. Immunol. Methods 1983, 65, 55-63.

(43) Rosenkranz, A. R.; Schmaldienst, S.; Stuhlmeier, K. M.; Chen, W.; Knapp, W.; Zlabinger, G. J. A microplate assay for the detection of oxidative products using 2',7'-dichlorofluorescin-diacetate. J. Immunol. Methods 1992, 156, 39-45. 